\title{
LODOVICO GIUSTINI AND THE EMERGENCE OF THE KEYBOARD SONATA IN ITALY
}

\author{
Daniel E. FreEMAN
}

\begin{abstract}
The twelve keyboard sonatas, Op. 1, of Ludovico Giustini (1685-1743) constitute the earliest music explicitly indicated for performance on the pianoforte. They are attractive compositions in early classic style that exhibit an interesting mixture of influences from Italian keyboard music, the Italian violin sonata, and French harpsichord music. Their unusual format of dances, contrapuntal excursions, and novelties in four or five movements appears to have been inspired by the Op. 1 violin sonatas of Francesco Veracini, a fellow Tuscan. Although the only source of the sonatas is a print dated Florence, 1732 , it is clear that the print could only have appeared between 1734 and 1740 . It was probably disseminated out of Lisbon, not Florence, as a result of the patronage of the Infante Antonio of Portugal and Dom João de Seixas, a prominent courtier in Lisbon during the late 1730's.
\end{abstract}

\section{Resumen}

Las doce sonatas para teclado, Op. 1, de Ludovico Giustini (1685-1743), constituyen la música más antigua explícitamente indicada para su interpretación en el pianoforte. Son composiciones atractivas en el estilo clásico temprano, que exhiben unà interesante mezcla de influencias de la música italiana de tecla, la sonata italiana para violín y la música francesa para clave. Su inusual formato de danzas, sus excursiones contrapuntísticas, y novedades en cuatro o cinco movimientos, parecen haberse inspirado en las sonatas para violín Op. 1 del toscano Francesco Veracini. Aunque la única fuente de las sonatas es un impreso datado en Florencia, en 1732, está claro que el impreso sólo pudo haber aparecido entre 1734 y 1740 . Fue posiblemente difundido a Lisboa, y no a Florencia, como resultado del mecenazgo del Infante Antonio de Portugal y Dom João de Seixas, relevante cortesano en Lisboa durante los últimos años de la década de 1730.

Of the many ironies and mysteries that surround Lodovico Giustini's Op. 1 pianoforte sonatas of 1732, perhaps the most frustrating of all is their modern obscurity among pianists. Even though they constitute by far the earliest surviving compositions unambiguously specified for performance on the pianoforte, few keyboard artists are acquainted with the composer's name, much less the sonatas he wrote. Equally disappointing, no complete recording of the sonatas has yet appeared, in spite of the availability of multiple facsimile editions for decades. ${ }^{1}$

1. Amazing as it seems, no less than five facsimile editions of the Giustini sonatas have appeared to date: Twelve Piano-Forte Sonatas of L. Giustini di Pistoja, ed. Rosamond E. M. Harding (Cambridge, 1933); Sonate da cimbalo di piano, e forte, Archivum musicum 49 (Florence, 1982); Sonate da cimbalo di piano, e forte, ed. Jan Nuchelmans, Utrecht Early Music Festival Facsimiles 1 (Utrecht, 1985); Sonate da cimbalo di piano, e forte, Clavecinistes europeéns du XVIIIe siècle 2 (Geneva, 1986); and Sonata da cimbalo di piano e forte, ed. Gerhard Doderer (Rio de Janeiro, 2002). The commentary

Anuario Musical, 58 (2003) 
Since the style of the Giustini sonatas is very much wedded to the capabilities of the Cristofori piano, an instrument little cultivated even by specialists who perform regularly on historical keyboard instruments, their modern neglect is understandable, but they do have much to recommend them as keyboard compositions. Still, the historical interest of the sonatas is what has chiefly been responsible for generating research about them, and in consideration of a substantial amount of new information that has come to light since Ala Botti Caselli's seminal 1978 study, ${ }^{2}$ it is high time to take stock of what has been learned with a view towards refining our knowledge of their genesis. A fresh appraisal of this question also provides an opportunity to present some new ideas concerning the stylistic antecedents of the sonatas and their relation to other early keyboard sonatas from Italy.

A good starting point for discussion is the title page and dedication attached to the original print, a perpetual source of puzzlement to researchers. This is the original text of the title page and dedication in Italian:

Sonate da cimbalo di piano e forte, detto volgarmente di martelletti, dedicate a Sua Altezza Reale il Serenissimo D. Antonio, Infante di Portogallo, e composte da D. Lodovico Giustini di Pistoia, Opera prima. Firenze DCCXXXII./Altezza Reale, Presento col più devoto rispetto a $\mathrm{V}$ [ostra] A[ltezza] $\mathrm{R}$ [eale] queste sonate, udite già da me con particolare soddisfazione nel mio soggiorno in Italia, e da quelli Intendenti di tal Professione giudicate di molto buon gusto. Io però non le pongo sotto i Reali suoi occhi, perchè le stimi adeguate al suo sopraffino discernimento, me perchè nella loro artificiosa consonanza ci rappresentano in qualche modo quella celeste Armonia, che fanno nella bella, e ben ordinata Anima di V. A. R. le più rare Virtudi tra di loro in dolce lega congiunte. Spero che la R. A. V. Ia quale di questa soave e dilettevole scienza, come di tutte l'altre, sa dare così accertato giudizio non solamente, ma con somma maraviglia di chi ha l'onore di udirla, sa eziando perfettamente esercitarla, non isdegnerà di compartire a questi Fogli un suo benignissimo sguardo in quelle ore, nelle quali suol dare à suoi sublimi pensieri qualche alleviamento, e riposo. Supplico umilmente V. A. R. a continuare sopra di me la sua sovrana, e benefica Protezione, e a permettermi che io abbia la sospirata gloria di protestarmi con profondissimo ossequio di V. A. R. umilissimo servo D. Giovanni de Seixas. ${ }^{3}$

provided in Doderer's preface, 'As sonatas de Ludovico Giustini di Pistoia (Florença, 1732): a primeira edição para o fortepiano', amply justifies the issuance of a new facsimile edition. The best recorded selection of Giustini sonatas presently available was made by Cremilde Rosado Fernandes on the 1767 Antunes pianoforte owned by the Shrine to Music Museum in Vermilion, South Dakota, USA (Numérica NUM 1047, 1996); it includes the Sonatas nos. 1,3,4,10, and 11. In 1994, Edward Parmentier recorded the Sonata no. 5 on the same instrument for a collection of works by several different composers (Wildboar WLBR 9401, n.d.). The only other selection presently available on compact disc is a recording of the Sonata no. 5 made by Luca Guglielmi on a modern copy of a Cristofori instrument (Stradivarius STR 33608, 2002). Mieczyslaw Horszowski's recordings of seven sonatas on the 1720 Cristofori piano in the Metropolitan Museum of Art in New York city (nos. 1, 2, 4, 5, 6, 7, 9, 10) were released in three different collections at various times on LP disc (Metropolitan Museum of Art NMA L1802, 1978; Metropolitan Museum of Art NMA L1803, 1978; and Titanic Ti 78-79, n.d.). James Bonn also recorded the Sonata no. 8 on the same instrument a few years earlier (released on Pleiades P105, 1977). In addition to these recordings on historical instruments, there is a recording from the late 1960s of the Sonata no. 3 made by Eugene List on a modern piano (Musical Heritage Society MHS 733, n.d.).

2. See Ala Botti Caselli, 'Le "Sonate di cimbalo di piano, e forte" di Lodovico Giustini: l'opera di un prete galante agli albori della sonata per pianoforte', Nuova rivista musicale italiana, 12 (1978), 34-66.

3. It reads as follows in English translation:

[12] Sonatas for the harpsichord with soft and loud, popularly called the hammered harpsichord, dedicated to his Royal Highness the Most Serene Dom Antonio, Infante of Portugal, and composed by Lodovico Giustini of Pistoia, Op. 1. Florence, 1732. 
Most of the laudatory dedications found in eighteenth-century music publications were prepared by composers who wished to flatter individuals known to them personally, but in this case, the dedication originates from an intermediary, one João de Seixas da Fonseca Borges (1691-1758), a musician, cleric, and courtier originally from Brazil. It is almost impossible to imagine that Lodovico Giustini, an obscure organist in Pistoia, could ever have met the recipient of the dedication, Dom Antonio de Bragança (1694-1757), a brother of King João V of Portugal, uncle of Domenico Scarlatti's famous pupil the Infanta Maria Barbara of Portugal, and a student of Scarlatti himself. There is a report that Dom Antonio visited Rome in $1714,{ }^{4}$ but no particular reason to believe that he ever visited Tuscany, which Giustini, as far as is known, never left during his entire lifetime (1685-1743). Many new details about Giustini's musical career have come to light since the time of Caselli's research, ${ }^{5}$ but at present, the only indication that he ever ventured outside his native Pistoia comes from a document of 19 June 1732 that records his request to be relieved of duties as organist of the Congregazione dello Spirito Santo in order to make a trip to Florence. ${ }^{6}$ He planned to arrive there on 1 July; by November of the same year at the latest he was back in Pistoia. ${ }^{7}$ One might think that Giustini traveled to Florence in order to promote sonatas he had already composed, but he might just as easily have come to Florence for an unrelated purpose and found sufficient inspiration in the city of Bartolomeo Cristofori (who died there in January of 1732) to compose the entire set during his stay. Regardless, it is certain that the Giustini sonatas originated in Tuscany. The dedication attached to them, however, must have been prepared in Lisbon. There is no other way that they could have been placed before Dom Antonio's 'royal eyes' after Seixas had heard them 'already' during a stay in Italy, nor

Royal Highness,

With the most sincere respect, I present to your royal highness these sonatas heard by me with particular satisfaction during my stay in Italy and judged by experts in the musical profession to be in very good taste. I place them before your royal eyes not because their merits are in proportion to your refined discernment, but because their artful consonance, expressed with such celestial harmony, will create in the beautiful and well-ordered soul of your royal highness the rarest virtues joined in sweet combination. I hope that your royal highness, proficient in the gentle and agreeable science of music, as in all others, who not only knows how to offer his astute judgment about it to the amazement of all who have the honor to hear it, but also knows how to practice it perfectly, will not disdain to impart to these pages his most benign glance, at which time they will offer great relief and repose to his sublime thoughts. I humbly beg your royal highness to continue his sovereign and beneficent protection over me and to allow me to have the longed-for glory of professing myself with the most profound obsequiousness the most humble servant of your royal highness Dom João de Seixas

4. See Santiago Kastner, Carlos de Seixas (Coimbra, 1947), 54. Kastner claimed that this visit was responsible for creating a connection between Domenico Scarlatti and the Portuguese royal family that led to Scarlatti's engagement in Lisbon, but offered no documentation to explain how he learned of it. The claim was ignored in Scarlatti biographies by Ralph Kirkpatrick, Roberto Pagano, and Malcolm Boyd, as well as the revised New Grove Dictionary of Music and Musicians (2001).

5. This is mainly due to the pains of Jean Grundy Fanelli, whose findings concerning Giustini's activities as an organist, harpsichordist and composer, are summarized in the biographical notice she prepared for the revised New Grove Dictionary of Music and Musicians.

6. See Umberto Pineschi, 'Jacopo Melani e Lodovico Giustini: organisti nella chiesa della Congregazione dello Spirito Santo di Pistoia', Bolletino storico pistoiese, 75 (1973), 93. The document in question is found in the Archivio di Stato di Pistoia, Atti della Congregazione dello Spirito Santo.

7. Ibid., 93. The Atti della Congregazione dello Spirito Santo preserve a request of Lodovico Giustini dated 20 November 1732 to admit his nephew Francesco Agostini to membership. 
would the request for continued 'protection' make any sense unless João de Seixas and Dom Antonio de Bragança were in close personal contact.

No researcher has ever tried to reconcile this anomaly before. One way to do so is to assert either that the Giustini print actually originated in Lisbon, not in Florence, or that it was published in Florence with the intent of distributing it out of Lisbon. Even if it was published in Florence, a date of 1732 for the release of the print is impossible to accept in consideration of the movements that can be established for João de Seixas. In fact, it has taken quite a long time for information about Seixas to penetrate into the musicological literature. In 1978, Ala Botti Caselli reported that nothing whatever was known about him, even after she had consulted with an authority as eminent as Santiago Kastner. ${ }^{8}$ Neither Caselli nor Kastner could much be blamed for their ignorance of a rather detailed biography of Seixas that was included in a commemorative history of the Benedictine monastery of Rio de Janeiro published in 1927; nobody could have suspected Brazilian origins for him. ${ }^{9}$ It can now be seen that Seixas was included in a number of Portuguese reference tools dating as far back as the eighteenth century, ${ }^{10}$ but the first music scholar to draw attention to the 1927 biographical notice and its significance for the Giustini sonatas was the American Robert Stevenson, who published a brief announcement in $1968 .{ }^{11} \mathrm{~A}$ short time later, William S. Newman mentioned Stevenson's findings in the third edition of his Sonata in the Baroque Era, ${ }^{12}$ then Stevenson himself published a more detailed study in 1979, partly to scold Caselli for her oversight. ${ }^{13}$

João de Seixas was born in Rio de Janeiro in 1691 and entered the Benedictine order in 1716. Apparently he received training as an instrumentalist at an early age and was able to compose as well. ${ }^{14}$ Seixas first came to Lisbon from Brazil in 1724 after finishing musical and theological studies in Rio de Janeiro and Salvador da Bahía. He received permission from Pope Benedict XIII to travel to Rome from Lisbon in 1727 , but he moved to Florence in 1728 following a rupture in diplomatic relations between the papacy and the Portuguese court. It was

8. See Caselli, 'Le Sonate di cimbalo di piano, e forte', 40.

9. See Mosteiro de S. Bento do Rio de Janeiro Abbadia Nullius de N. S. do Monserrate: O seu historico desde a fundação até ao anno de 1927 (Rio de Janeiro, 1927), 172-76. Transcriptions of documents used as the basis of the Seixas biography contained in this work are found in E. M. Maia da Silva Lessa, 'Os mosteiros beneditos portugueses (séculos XVII a XIX): Centros de ensino e prática musical' (diss., Universidade Nova de Lisboa, 1998), 583-84. Excerpts are included in the preface to the 2003 Doderer edition listed in $\mathrm{f}$. 1 .

10. Notices about Seixas can be found in Diôgo Barbosa Machado, Biblioteca Lusitana, vol. 2 (Lisbon, 1747), 750; J. de Vasconcelos, Os músicos portugueses, vol. 1 (Porto, 1870), 106; Ernesto Vieira, Diccionario biographico de músicos portugueses, vol. 1 (Lisbon, 1900), 423; and a late eighteenth-century biographical dictionary of Portuguese musicians available as José Mazza, Dicionário biográfico de músicos portugueses, ed. José Augusto Alegria (Lisbon, 1945$), 30$.

11. See Robert Stevenson, 'Some Portuguese Sources for Early Brazilian Music History', Yearbook of the InterAmerican Institute for Musical Research, 4 (1968), 3-6.

12. See William S. Newman, The Sonata in the Baroque Era, 3rd ed. (New York, 1972), 404. The same citation is found in the fourth edition (New York, 1983) on p. 408.

13. See Robert Stevenson, 'The Brazilian Benedictine Bishop Who Launched the First Piano Publication (1732)', Inter-American Music Review, 1 (1978-79), 211-15.

14. See Mosteiro de S. Bento, 173; Stevenson, 'The Brazilian Benedictine Bishop', 213. The only indication that Seixas was active as a composer comes from Mazza, Dicionário biográfico de músicos portugueses, 30 , in which he is identified as the author of 'diversas obras em muzica'. 
in Florence that Seixas first became a courtier. After making the acquaintance of a Florentine nobleman, he was introduced to the highest aristocracy in Florence and enjoyed the favor of Gian Gastone, grand duke of Tuscany. Seixas returned to Rome in October of 1732, thus it was only during the brief period July-October 1732 that Seixas and Giustini were both present in Florence. Seixas moved back to Lisbon from Rome early in 1734 after he had been consecrated titular Bishop of Aeropolis by Pope Clement XII. From this time until his return to Brazil in 1740, Seixas was a favored courtier in Lisbon, highly regarded by King João V, the Patriarch Cardinal, the Papal Nuncio, and (judging from the dedication attached to the Giustini sonatas) Dom Antonio de Bragança. The dedication cannot have been authored before the year 1734, when Seixas likely came into close personal contact with members of the Portuguese royal family for the first time, nor can it post-date his permanent departure from Europe in 1740.

Important evidence suggesting that the Giustini print did not circulate in eighteenthcentury Italy can be gleaned from an analysis of the surviving exemplars. In fact, startling disparities are evident when one compares the sources of Giustini's sonatas with those of the three important prints of keyboard sonatas that had appeared in eighteenth-century Italy by about 1732: Domenico Zipoli's Sonate d'intavolatura per organo e cembalo (Rome, 1716), Azzolino Bernardino della Ciaja's Sonate per cembalo (Rome, 1727) and Francesco Durante's Sonate per cembalo (Naples, ca. 1732). Each of the latter collections is preserved in an assortment of archives in Italy, Germany, and western Europe. ${ }^{15}$ A similar pattern of dissemination can be discerned from the printed sources of Padre Martini's two sets of keyboards sonatas (published in Amsterdam in 1742 and 1747) and manuscript sources associated with the sonatas of Benedetto Marcello and Domenico Alberti, the two most influential Italian composers of keyboard sonatas during the earliest phases of classicism in music. ${ }^{16}$

In the case of the Giustini print, however, no exemplars are known to be preserved anywhere in Italy or Germany, and it is particularly curious that no copy of it survives from Padre Martini's collection in Bologna. Rather, the surviving copies reflect a pattern of dissemination oriented towards western Europe alone, the most important reason why Giustini's sonatas were first brought to the attention of the musicological community out of Great Britain, and not out of Italy. Under normal circumstances, one would expect that a collection as momentous as Giustini's Op. 1 would have been trumpeted by the nationalist musicologist Fausto Torrefranca, but the lack of sources in Italy made it unavailable to him for study, as he himself confessed. ${ }^{17}$ Of the six copies of Giustini's Op. 1 reported in the musicological literature up to this time, the

15. According to RISM A, there are seven exemplars of the original print of Zipoli's sonatas preserved in Italian archives, and one each in Belgium, Germany, France, Great Britain, and the Netherlands. Della Ciaja's sonatas are preserved in two British archives, one Italian archive, one German, and one French. Durante's sonatas are preserved in four archives in Italy, three in Germany, and one each in Great Britain, the United States, The Netherlands, Sweden, and Croatia.

16. For exemplars of Martini's keyboard prints, see RISM A. For sources of Alberti's music, see Wilhelm Wörmann, 'Die Klaviersonaten Domenico Albertis', Acta musicologica, 27 (1955). 84-112. For Marcello, see Eleanor Selfridge-Field, The Music of Benedetto and Alessandro Marcello: A Thematic Catalogue with Commentary on the Composers, Repertory, and Sources (Oxford, 1990).

17. See Fausto Torrefranca, Le origini italiane del Romanticismo musicale (Turin, 1930), 366. 
only ones known to Giustini's great early advocate, the Englishwoman Rosamond Harding, were three preserved in Great Britain, Portugal's political ally and close commercial trading partner of several centuries' standing by the early eighteenth century. ${ }^{18}$ The lack of exemplars from Lisbon itself can be attributed to the loss of cultural artifacts in the aftermath of the great earthquake of 1755, but the existence of an exemplar in Coimbra can leave no doubt that the sonatas were known in Portugal. ${ }^{19}$ The remaining two copies are both preserved in nations that were traditional maritime trading partners of Portugal on the Atlantic Ocean. ${ }^{20}$ As far as manuscript sources are concerned, recent research has uncovered only a nineteenth-century copy of the Giustini print in Florence, ${ }^{21}$ and one sonata (no. 7 in $\mathrm{G}$ major) in an eighteenth-century manuscript in Brescia. ${ }^{22}$ The sonata in Brescia is designated a Sonata per cembalo, and it contains no dynamic markings of any type, thus its connection to the printed collection is questionable.

To believe that the Giustini print was actually printed in Florence, one would have to entertain the idea that it was prepared by Florentine engravers specifically for the court of Lisbon without any copies being offered for sale in Italy. A subsidy from the court of Portugal (or from Seixas personally) might have made it attractive for an Italian printer to prepare the sonatas for distribution abroad. They may also have been engraved in Lisbon, although there is no evidence at present of any music engravers active in Lisbon in the 1730s. Unfortunately no watermarks are available to assist in verifying the origins of the paper. The absence of the name of an Italian printer certainly does not injure the theory of non-Italian origins for the print, but it is not at all unusual in eighteenth-century music publishing for a printer's name to be missing (to say nothing of a place and date of publication). Gerber's remark that Giustini was the author of a set of keyboard sonatas published in Amsterdam in 1736 only confuses the matter even more. ${ }^{23}$ An undated re-print of the Giustini sonatas brought out by Gerhard Friedrich Witvogel in Amsterdam is preserved in Stockholm, but its date of issue has been estimated between 1742 and $1746 .{ }^{24}$ It is possible that the date 1736 found in Gerber's dictionary might actually refer to the original print, not the Amsterdam re-print, or that the first print might have originated in Amsterdam

18. See Harding, Twelve Piano-Forte Sonatas of L. Giustini, xiv. Harding reported copies in the British Library (RISM GB-Lbm), Rowe Music Library, King's College, Cambridge (GB-Ckc), and the private collection of Harold Reeves. The copy in the Reeves collection is now housed in the Yale Music Library (US-NH). I am grateful to Suzanne Eggleston Lovejoy of Yale Music Library for making this identification for me. Harding's study, 'The Earliest Pianoforte Music', Music \& Letters, 13 (1932), 194-99, was the earliest attempt at a detailed examination of the origins and style of the Giustini sonatas.

19. The copy of Giustini's sonatas preserved in the library of the University of Coimbra is cited in Maria Luisa Lemos, Impressos musicais da Biblioteca Geral da Universidade de Coimbra (Coimbra, 1980), 93. There is no mention of this exemplar in RISM A.

20. RISM A reports exemplars in the music department of the Bibliothèque Nationale in Paris (F-Pn) and the castle collection of Count Bentinck in Amerongen, The Netherlands (NL-AN).

21. See Caselli, 'Le Sonate di cimbalo di piano, e forte', 34, f. 2.

22. Ms. vari 34 of the library of the Conservatorio Statale di Musica Luca Marenzio (RISM I-BRc).

23. See Ernst Ludwig Gerber, Neues historisch-biographisches Lexikon der Tonkünstler (1812-1814), ed. Othmar Wessely, part 2 (Graz, 1966), col. 338. All that Gerber said about Giustini was that he was 'ein Instrumentalkomponist von Pistoja, lebte ums J. 1736, um welche Zeit zu Amsterdam XII Klaviersonaten gestochen wurden'.

24. See Ernst Ferdinand Kossmann, 'Het fonds van G. F. Witvogel, Amsterdam 1730-1742', Het boeck, vol. 15 (The Hague, 1938), 62. The unique exemplar is preserved in Stockholm, Statens Musikbibliothek (RISM S-Skma). 
instead of Florence or Lisbon. In any case, there is no reason to doubt that Giustini's collection of sonatas was assembled in Florence in 1732, just as the title page specifies, but it could only have been issued as a publication between 1734 and 1740, when João de Seixas was resident in Lisbon. The dedication clearly indicates that Seixas had refreshed his acquaintance with the Giustini sonatas only after he returned to Portugal from Italy. Publication in Florence is dubious, but no matter what the venue of publication, it is unlikely that the print was disseminated out of Florence.

Frustrating difficulties with dating and provenance such as these are very much the norm for sources associated with the early keyboard sonata in Italy, and the same can be said for questions relating to genre definition. Italian keyboard sonatas of the early eighteenth century were the result of an interesting period of experimentation that came in response to a recognition that the time had come for keyboard instruments to participate as obbligato soloists in two genres from which they had traditionally been excluded: the sonata and the concerto. This idea was very much "in the air" throughout Europe in the 1720 s and $1730 \mathrm{~s}^{25}$ It is not accurate to say that keyboard sonatas were completely new to Europe at this time, but earlier they had appeared only sporadically, with a connotation of novelty about them. The 1720 s was the key decade in which keyboard sonatas began to appear in significant numbers in several parts of Europe; the key decade for the keyboard concerto was the 1730 s. $^{26}$

Italy was clearly at the forefront in establishing traditions of sonata composition for keyboard instruments, just as it was for sonatas for other instruments. ${ }^{27}$ William S. Newman took a special interest in tracing the origins of the keyboard sonata in the seventeenth and early eighteenth centuries, in the process bringing to light many important sources, but also obscuring the significance of others. In Newman's work, one is left with the impression that sonatas for stringed keyboard instruments were the only ones that really mattered, thus the existence of sonatas designated for organ was duly recorded, but otherwise systematically ignored. From the seventeenth century, Newman recognized only three composers from Italy who produced sonatas for stringed keyboard instruments: Gioanpietro Del Buono, Giuseppe Piccini, and Gregorio Strozzi. ${ }^{28}$ The format of their compositions is diverse. Del Buono's thirteen sonatas of 1641 are contrapuntal studies based on cantus firmus technique, whereas Piccini's undated two-movement sonata consists of a preludial introduction followed by a contrapuntal "canzona." Strozzi's three

25. Thus a remark of Johann Kuhnau in his Neuer Clavier-Übung of 1692 that posed the question why composers should not write sonatas for keyboard went largely unanswered for several more decades.

26. In William S. Newman, 'A Checklist of the Earliest Keyboard "Sonatas" (1641-1738)', Music Library Association Notes, 11 (1954), 210-12, the great burgeoning of keyboard sonatas in Europe is considered to have begun after 1740 , however the documentation provided in the article belies the claim, even aside from the fact that the study ignores large numbers of keyboard sonatas from the 1720 s and 1730 s that only circulated in manuscripts.

27. Before the eigheenth century, keyboard sonatas outside of Italy were quite rare, although there was a 'sonatina' for keyboard by Heinrich Schmelzer in 1681, a "sonatina" for organ by Christian Ritter perhaps also from the 1680s, a sonata for keyboard in Johann Kuhnau's Neuer Clavier-Übung of 1692, and a sonata for keyboard of ca. 1690 by the Dutchman Sybrandus van Noordt. A 'sonata' of Johann Kaspar Kerll that appears in an anthology of organ pieces compiled in the late 1690 s by Giulio Cesare Aresti, the Sonate da organo di varii autori (Bologna, n.d.) is designated a 'canzona' in other sources. 28. See Newman, 'A Checklist'. 
sonatas of 1687 were conceived as variation canzonas. Manuscripts brought to light by Alexander Silbiger in the facsimile series 17th Century Keyboard Music (New York and London, 1987) have yielded a few more examples of keyboard pieces from seventeenth-century Italy that were designated 'sonatas', but they also lack a strong generic identity. ${ }^{29}$

It is difficult to fathom just why Newman chose to minimize the importance of singlemovement contrapuntal organ sonatas from the seventeenth and early eighteenth centuries, as if they somehow did not count as 'true' sonatas in spite of the clear designation in sources and considerable generic cohesion. At one point, Newman even said that they should be excluded from consideration as antecedents for the eighteenth-century keyboard sonata. ${ }^{30}$ This was a most unfortunate judgment. Contrapuntal organ sonatas in single movements were clearly a stylistic resource used by composers of sonatas for stringed keyboard instruments in the 1720s and 1730s, including Lodovico Giustini (who made his living as an organist) and Domenico Scarlatti (see, for example, the sonatas K. 30, 41, 58, 69, 93, 287, and 417). The tradition of organ sonatas of this type date back to several collections from the early seventeenth century produced by the Bolognese organist Adriano Banchieri. Of more immediate interest to this study is an important compilation of organ sonatas that appeared in the late 1690s: Giulio Cesare Aresti's Sonate da organo di varii autori (Bologna, n.d.). Some of the same sonatas plus a good many more appear in a manuscript intended mainly for the use of harpsichordists that has been reproduced in the series 17 th Century Keyboard Music. ${ }^{31}$ The fact that these sonatas appeared also in a collection of harpsichord music reveals to what extent they belong to a shared tradition of keyboard composition.

The first two decades of the eighteenth century saw few new keyboard sonatas produced in Italy, partially a reflection of weakened traditions of Italian keyboard music in general at the time. One set, a collection of sonatas for one and two harpsichords by Bernardo Pasquini in an autograph manuscript bearing dates between 1703 and 1704, might actually date from the previous century, considering the age of the composer at the time (he lived from 1637 to 1710 ). ${ }^{32}$

29. The so-called Feininger manuscript (housed in Trent, Museo Provinciale d'Arte, Biblioteca Musicale), reproduced as vol. 16 of the series 17th Century Keyboard Music, was probably copied about the year 1600 in north central Italy, according to Alexander Silbiger. On fol. 21 ' -22 there is an anonymous 'sonata di spinetta' that might just as well have been designated an 'intrada' (a short prelude) based on its style in comparison to other compositions in the manuscript. In his preface, Silbiger raises the possibility that the designation could have been added later in the seventeenth century. The manuscript Rome, Biblioteca del Conservatorio di Musica Santa Cecilia, A/400, reproduced as vol. 13 of the series $17 t h$ Century Keyboard Music, was probably copied in Rome or Naples sometime in the late seventeenth century or early to mideighteenth century, according to Alexander Silbiger. It contains a piece designated "sonata" with attribution to Ercole Pasquini, a composer who died between 1608 and 1619. More precisely, it follows a "canzona" of Pasquini with the indication '[un']altra sonata di Ercole Pasquino'. The imprecision in the designation of the two compositions is obvious. The manuscript Bologna, Civico Museo Bibliografico Musicale, DD/53, reproduced in vol. 10 of the series 17th Century Keyboard Music, was completed at an unknown location no earlier than the 1720 s, according to Alexander Silbiger. Besides eighteen keyboard sonatas that belong to the tradition of single-movement contrapuntal organ sonatas, there is a 'sonata cromatica' attributed to Tarquinio Merula (ca. 1595-1665), perhaps mistakenly, that could just as easily have been designated a 'canzona'. Most of the other sonatas bear no attribution and are paired with improvisational 'preludes'. Silbiger has put forward the theory that most of the anonymous sonatas are actually the work of Carlo Francesco Pollaroli.

30. Newman, 'A Checklist', 207-8.

31. Bologna, Civico Museo Bibliografico Musicale, MS DD/53 (see f. 29).

32. London, British Library, MS Add. 31501, reproduced as vol. 8 of the series 17th Century Keyboard Music. 
The inconsistent practice in designating the pieces in this collection has led to a bit of confusion in the work of Newman and others about the true number of sonatas it actually contains. ${ }^{33}$ The formal designation 'sonata' appears on only twelve of the fourteen pieces for two harpsichords, thus Newman did not recognize two of them as sonatas, even though they were incorporated into a consecutive numbering scheme 1-14 (the first two are numbered 1-2, but the designation 'sonata' is missing). There are no generic designations for the fourteen pieces for solo harpsichord interspersed among them, but there is no reason not to consider them 'sonatas' also, since the basic conception does not differ in any way from the twelve pieces for two harpsichords that do carry designations: all of the pieces take the form of multi-movement continuo parts that resemble the bass lines of solo and trio sonatas for stringed instruments. Most of the sonatas are cast in two to four movements with alternating meters, but no tempo markings. The section of the manuscript that contains these twenty-eight pieces is clearly meant to offer users fourteen sonatas for solo harpsichord and fourteen sonatas for two harpsichords. Newman claimed that the sonatas for two harpsichords may be the first multi-movement sonatas for keyboard, but he did not recognize that some of the organ pieces from the Aresti anthology could also be described as multi-movement sonatas for keyboard (many of the keyboard pieces in this collection do not require pedal) ${ }^{34}$ Keyboard pieces that take the form of continuo basses are not unheard of by any means from seventeenth-century Italy; many examples are found in one of the manuscripts reproduced in the series 17 th Century Keyboard Music. ${ }^{35}$

A much more serious error on the part of William S. Newman concerns the way that he buried the significance of the keyboard sonatas of Domenico Zipoli. In the 1710s, it is clear that new traditions of keyboard sonata composition started to emerge in Italy. It is possible that the important output of Benedetto Marcello in Venice began during this decade, but there can be no doubt of the chronological landmark represented by Zipoli's Sonate d'intavolatura per organo, $e$ cimbalo (Rome, 1716). Strangely, William S. Newman tried to negate the clear intent of the source and refused to acknowledge the pieces it contains as 'true' sonatas. To Newman, the designation 'sonata' was held to be invalid for the entire contents of the print, as if he knew better than the composer himself what should properly be considered a 'sonata' ${ }^{36}$ The four sonate da camera for harpsichord in Zipoli's Op. 1 actually form a prototypical cycle in the sense that they are fully-notated works for a stringed keyboard instrument in more than one movement. Moreover, the pieces are dominated by movements cast in binary form (unlike Pasquini's

33. See Newman, 'Checklist', 206, 209-10; Newman, The Sonata in the Baroque Era, 4th ed., 160.

34. Sonatas in which a three-movement format can be recognized include nos. 5, 16, and 18. The Sonata no. 6 of the Aresti anthology is a contrapuntal study followed by a dance-like movement in $6 / 8$ time.

35. Rome, Biblioteca del Conservatorio di Musica Santa Cecilia, MS A/400, vol. 13 of the series.

36. In his The Sonata in the Baroque Era, 4th ed. (New York, 1983), 196, Newman made this odd comment about them: "...they are not of direct concern here, since "Sonate" appears only as a generic term in the over-all title, with no further application to the individual pieces'. No matter what Newman was trying to express with this remark, it is very clear that the collection was meant to offer four sonate da camera for keyboard. There can be no question that the indentation and larger type that accompany the 'preludes' of these sonatas were intended to signify the beginning of distinct cycles of sonata movements. 
sonatas). The vast majority of the keyboard sonatas that appeared during the remainder of the eighteenth-century in Italy can be described in precisely the same terms. It is not at all an exaggeration to regard Zipoli's Op. 1 as a confirmation of the beginning of fresh traditions of keyboard music in Italy.

As sonatas replaced toccatas as the quintessential vehicle of expression for Italian composers of keyboard music during the first half of the eighteenth century, Italian keyboard composition underwent a thorough-going rejuvenation. For a time, Italian keyboard music regained something like the prestige it had enjoyed in the sixteenth and seventeenth centuries, an achievement little recognized today. Much of the reason for the obscurity of this repertory is its association with a style of early classicism that has a bad reputation at present for a lack of depth. In Italy itself, no composer ever emerged to transcend its limitations completely, although the expatriates Giovanni Benedetto Platti in Germany and Domenico Scarlatti in Iberia succeeded to a large degree. As a result, the great flowering of Italian keyboard music between the 1720s and 1760 s may be described at best only as a 'silver age', but it was the last period in music history in which Italy provided significant stylistic leadership in the composition of keyboard music.

For the style critic, the challenge of evaluating the repertory of the earliest Italian keyboard sonatas is to try to understand how the composers reconciled long-standing traditions of keyboard composition and keyboard improvisation with contemporary notions of what could reasonably be designated a 'sonata'. Eighteenth-century composers relied heavily on generic models for guidance in working out their compositions, but for a time in the early eighteenth century, there were no well-established precedents governing the format of keyboard sonatas. The impression of confusion and individuality left by the composers of Italian keyboard sonatas of the 1720s and 1730s derives from the freedom they felt to seek their own methods of incorporating elements from existing traditions of keyboard music and sonatas for stringed instruments. This state of affairs changed rather quickly, however. Already by the $1740 \mathrm{~s}$, a dynasty of Venetian composers had emerged to offer widely-copied standards for the creation of keyboard sonatas, to the extent that the keyboard sonata became the last important musical genre whose style and format was shaped decisively by Venetian composers. The most important figures were Benedetto Marcello, Domenico Alberti, and Baldassare Galuppi, whose models for keyboard sonata composition were respected by almost all Italians who subsequently cultivated the genre in the mid-eighteenth century. ${ }^{37}$ The only great exception was Domenico Scarlatti, whose brilliant cultivation of single-movement sonatas continued throughout his career.

The stylistic eclecticism of Giustini's collection is quite typical of Italian keyboard music of the $1720 \mathrm{~s}$ and $1730 \mathrm{~s}$. What one usually encounters is a mixture of elements borrowed from violin sonatas, Italian toccatas, Italian organ sonatas, French harpsichord music, and what appear to be improvisational traditions. The extent to which violin sonatas were used as a stylistic resource for the early composers of Italian keyboard sonatas can sometimes be startling, but it

37. This phenomenon is documented in my chapter 'J. C. Bach and Early Classic Italian Masters', in Robert L. Marshall, ed., Eighteenth-Century Keyboard Music (New York, 1994), 230-69. 
should not be surprising. Keyboard instruments have always been quintessential instruments of transcription, and furthermore, the genres associated with keyboard music in the eighteenth century were decidedly 'weak'. In other words, keyboard genres were susceptible to influence from more prestigious genres of vocal and instrumental music, whereas they exercised little or no influence on outside genres themselves.

Solo sonatas for violin were the most prestigious type of chamber music produced in Italy in the early eighteenth century, and they would have provided the most obvious models of 'sonata style' for composers of that time. The style of trio sonatas is discernible in some seventeenthcentury keyboard music, ${ }^{38}$ but in the eighteenth century, the solo sonata was effectively the only style of string chamber music that Italian composers used as a resource for keyboard music. ${ }^{39}$ Continuo textures common in violin sonatas were not at all difficult to replicate on keyboard instruments. One of the standard performing options for simpler violin sonatas of the early eighteenth century was to play them as transcriptions for keyboard, the violin part in the right hand, the continuo part in the left. Movements from Corelli's Op. 5 of 1700 were published explicitly as keyboard pieces even into the late eighteenth century, and in 1720 a collection of sonatas was printed that was designed to be played either by a keyboard soloist or by a violinist with continuo accompaniment: Giuseppe Maria Buini's Suonate per camera da cembalo, ò violino, e violoncello, Op. $1 .^{40}$ It was a small step to transfer the continuo textures of solo sonatas into compositions conceived for keyboard from the start, as can be seen in Example 1. The outlines of continuo texture are easily recognizable in the soprano and bass parts, whereas the interior voices give the impression of a continuo realization. In some cases, the Venetian Benedetto Marcello produced thematic material much more idiomatic for violin than for keyboard, and this phenomenon can be seen in Giustini's work as well (see Example 2).

Other Italians wrote keyboard sonatas that owed very little to the style of sonatas for stringed instruments. One was the Neapolitan Francesco Durante, another the Sienese Azzolino Bernardino della Ciaja, both of whom wrote sonatas based on a mixture of improvisational and contrapuntal styles firmly rooted in keyboard traditions. Della Ciaja's sonatas are constructed on a rigid four-movement plan that opens with an improvisational 'toccata', then continues with a contrapuntal 'canzone' and two binary movements ('tempi'). In a recent edition of Della Ciaja's

38. See, for example, a discussion of trio sonata textures found in keyboard music in Giorgio Pestelli, 'Bach, Handel, D. Scarlatti and the Toccata of the Late Baroque', in Bach, Handel, Scarlatti Tercentenary Essays, ed. Peter Williams (Cambridge, 1985), 279-81.

39. J. S. Bach, however, found a great deal of inspiration in trio-sonata texture. Various sonatas for organ and string or wind soloists plus obbligato keyboard form a true repertory of 'trio sonatas' supplemented by only one conventional trio sonata (BWV 1039) that is accepted today as authentic. In the organ sonatas BWV 525-30, it has long been recognized that the parts for the manuals correspond to the customary treble voices of trio sonatas, whereas the pedal is equivalent to the continuo. Less well acknowledged is the way that several movements from the sonatas for violin, cello, and flute with obbligato keyboard accompaniment (BWV 1014-19, 1027-29, and 1030-32) resemble trio sonatas in which the wind or string part corresponds to one of the two treble parts, the right hand of the keyboard corresponds to the other one, and the left hand of the keyboard corresponds to the continuo part.

40. There is also a group of keyboard sonatas by Domenico Scarlatti that can be played either as keyboard solos or as sonatas for a treble instrument plus basso continuo. (K. 32, 34, 40, 42, 59, 61, 63-64, 67, 70-73, 77-78, 80-81, 83b, 85, 8891, 94). 
sonatas, the editor tried to relate the 'canzoni' to traditions of French organ music, ${ }^{41}$ but he probably would have been wiser to compare them to Italian organ sonatas. The basic conception of the 'canzoni' is almost indistinguishable from the style of single-movement organ sonatas that appear in the Aresti collection, but there is an important accommodation in Della Ciaja's work for harpsichord style: a plethora of agréments. The French-style ornaments do make the contrapuntal movements more idiomatic for harpsichord, but they need not mask the influence of Italian organ sonatas. The archaic designation 'canzone' for these movements seems curious for the 1720s, but the composer did face a generic dilemma. In organ music, each of the fugal movements could be designated a 'sonata' individually, but there could not be a movement designated 'sonata' within a multi-movement cycle also designated 'sonata'. To avoid redundancy, Della Ciaja employed the archaic term 'canzone'. Francesco Durante chose to call the contrapuntal pieces within his two-movement sonatas 'studi' perhaps as a solution to the same problem. Each of his 'studi' is followed by a whimsical 'divertimento' that may or may not include repeat signs, but is always cast in binary form. Durante also introduced agréments that made the contrapuntal movements more idiomatic for harpsichord.

The Bolognese Padre Martini wrote sonatas that juxtapose the style of the toccata of Alessandro Scarlatti with French dances, among them the famous Gavotte from his sonatas of 1742. Martini went much further than Della Ciaja in incorporating French elements, including style brisé, which has an arresting sound in Italian music of this period, almost like a 'loss of face'. In general, Italian composers of the early eighteenth century were so secure in their position of superiority that they found little reason to pay much attention to the output of French composers, but the style of the eighteenth-century clavecinistes was successful enough in the face of weakened Italian traditions in the early eighteenth century to prompt some Italian composers to adopt a few traits of French keyboard music style.

The most important models for the mid-eighteenth-century were developed by the Venetian Domenico Alberti, a composer whose name is universally known to pianists today for the accompanimental pattern he created, but whose music is no more familiar than Giustini's. In the 1730s, Alberti developed a kind of keyboard sonata that shed itself of continuo textures and violinistic idioms and replaced the old traditions of keyboard style with newer accompanimental figures (most notably the 'Alberti bass') and a 'singing' melodic style compatible with early classic notions of 'naturalness' in music. This new 'singing' style with Alberti bass strikes some critics today as more effective when played on pianos with Cristofori action than on harpsichord, and it may well have been conceived with the pianoforte in mind, in spite of the lack of early sources that specify performance on this instrument explicitly. ${ }^{42}$ Building on the work of

41. See the preface to Azzolino Bernardino Della Ciaja, 6 sonate op. IV per clavecembalo, ed. Francesco Tasini (Bologna, 1997), iv.

42. The suitability of the Cristofori piano for a 'cantabile legato' style and efforts of instrument makers to enhance this capability has been commented on recently in David Sutherland, 'Bartolomeo Cristofori's Paired Cembalos of 1726', Journal of the American Musical Instrument Society, 26 (2000), 28-29. 
Benedetto Marcello (whose sonatas consist of opening slow movements followed by an indeterminate number of faster movements), Alberti standardized rules that governed the arrangement of movements and reduced their number to only two. French elements were banished, and the only dance movements generally permitted were minuets. In two-movement schemes, the first movement was generally the slower one of the two, but if light movements such as minuets or variations were present, a fast movement in binary form would be placed first. In three-movement schemes written by Alberti's successors, there was also a tendency to begin with slow movements and reserve minuets and variations for the last.

Alberti's importance as a trend-setter was acknowledged in an astonishing back-handed way by Domenico Scarlatti, at least if it is possible to trust a remark passed on to Charles Burney by one of Scarlatti's acquaintances, the harpsichordist L'Augier. Burney reported the following observation about Scarlatti:

He used to say, that the music of Alberti, and of several other composers, did not in the execution want a harpsichord, as it might be equally well, or perhaps better expressed by any other instrument; but as nature had given him ten fingers, and as his instrument had employment for them all, he saw no reason why he should not use them. ${ }^{43}$

What Scarlatti seemed to decry with these remarks was the marked de-emphasis on virtuosity that Alberti's 'singing' style mandated. It is not difficult to see that Scarlatti himself realized that his manner of writing keyboard sonatas (more 'figural' than 'singing') was more in the style of the composers who preceded Alberti's rise to prominence. Scarlatti's sonatas shared many kinds of keyboard idioms with his Italian contemporaries, but perhaps the most important element that bound Scarlatti to Italian traditions of keyboard sonata composition in the mid-eighteenth century was binary form. The presence of binary form with repeat signs, whether in a single movement or one of several, was generally the critical feature that qualified a keyboard composition as a 'sonata' among Italian composers of the mid-eighteenth century. In the seventeenth century (as far as a generic identity for keyboard sonatas can be established), the critical defining feature was the presence of contrapuntal technique.

Lodovico Giustini's personal methods of reconciling traditions of keyboard music and sonata composition appear to have taken as their principal point of departure compositional models provided by composers from his native Tuscany. Just how his own experience as a keyboard performer influenced the composition of the Op. 1 sonatas is impossible to say. For many decades, it was believed that no other compositions by Giustini had survived into modern times. Giustini's activities as a composer of sacred vocal music have been illuminated gradually

43. See An Eighteenth-Century Musical Tour in Central Europe and The Netherlands, ed. Percy A Scholes, vol. 2 of Dr. Burney's Musical Tours in Europe (London, 1959), 87. Burney ran into L'Augier in Vienna in 1772. The implications of the remark about the employment for all ten fingers is discussed in Roberto Pagano, 'Piena utilizzazione delle dieci dita: una singolare applicazione della parabola dei talenti', Chigiana, 40 (1985), 81-107. 
over the years, ${ }^{44}$ but it is difficult to ascribe much (if anything) in the style of Giustini's keyboard sonatas to his experience composing this type of music. Rather, it is much more fruitful to examine certain precedents in keyboard works written by other Italian composers, plus a collection of music by one of the most important figures associated with the baroque violin sonata: the Florentine Francesco Maria Veracini. The great collection of Veracini sonatas that was circulating ca. 1730 was the composer's own Op. 1, which was composed between the years 1717 and 1723 while he was employed in Dresden at the court of Saxony. ${ }^{45}$ During the period 1723-33, Veracini was once again resident in Florence and could easily have made personal contact with Giustini. Regardless, there can be little question that Veracini's Op. 1 provided significant models for Giustini, in particular his schemes of arranging sonatas into cycles of four and five movements (see Tables 1-2).

Veracini's Op. 1 was set up in an interesting fashion in which the first six sonatas are all in minor key conforming to the general plan of the Corellian sonata da camera (that is, a prelude plus a series of dance movements), whereas the second group of six are all in major key conforming to the general plan of the sonata da chiesa (that is, a series of non-dance movements in alternating slow and fast tempos, the second movement usually fugal). Veracini's first collection of sonatas, composed in Venice in 1716, contains no dances at all, and the likely reason for their inclusion in his Op. 1 sonatas is the fact that they were composed for the court of Dresden. German musical culture in the early eighteenth century regarded as one of its greatest advantages a propensity to combine the best features of French and Italian music. Veracini in Dresden made a number of concessions to French taste, one of them his cultivation of French dances common both to the German dance suite and the Corellian sonata da camera. Some of the movements labeled 'aria' by Veracini are meant to be dance-like as well, following the use of the term 'air' as it appears in French theater music to mean a binary dance not belonging to one of the standard recognized categories (the added indication 'cantabile' is needed to signal a connection with vocal music in one of Veracini's 'arie'). The introduction of a French rondeau into one of the sonatas is somewhat extraordinary for an Italian composer of violin sonatas.

Giustini's sonatas are constructed very much along the same lines as Veracini's sonate da camera: cycles of four or five movements based on the idea of beginning with a slow prelude or dance movement and continuing with an indeterminate number of dances and novelties. The distinction between sonata da camera and sonata da chiesa in late baroque chamber music is often artificial or blurred, and this is precisely what we see both in Veracini's and Giustini's sonatas. Alongside the preludes and dances typical of the sonata da camera, there are also fugal movements (which Giustini usually called 'canzoni') and non-dance movements interspersed

44. Giustini has now been identified as the author of a sacred cantata for two voices (1724), the oratorio La fuga di Santa Teresa (1726), arias for the pastiche Il martirio di San Jacopo (1727), and an unknown oratorio performed in Pistoia in 1739. See Jean Grundy Fanelli, A Chronology of Operas, Oratorios, Operettas, Cantatas and Miscellaneous Stage Works with Music Performed in Pistoia, 1606-1943 (Bologna, 1998), 36, 38, 39, and 45.

45. For a detailed discussion of these sonatas, see John Walter Hill, The Life and Works of Francesco Maria Veracini (Ann Arbor, 1982), 153-71. 
among the dances. If fugal movements are present, one always appears as the second movement in the manner of sonate da chiesa, just as in Veracini's cycles. If there is more than one fugal movement, the second one appears as the last movement (cf. Giustini's Sonata No. 3 with Veracini's Sonatas No. 9 and 11). We also see what appear to be evocations of French overture style in the G-minor sonatas that open each of the collections (see Example 3), an occurence as unusual in Italian keyboard sonatas as it would have been in Italian violin sonatas of the day. ${ }^{46}$ In 1732, the inclusion of French rondeaux in Italian keyboard sonatas was unprecedented (judging from the surviving sources), but there are no less than three in Giustini's sonatas. Giustini also introduced his own version of the 'arie' that appear in Veracini's sonatas with movements designated 'dolce' (see Example 4).

To gain a sense of how exceptional Giustini's layouts are (and how closely bound they really are to Veracini's conception), one has only to look at the violin sonatas of the leading Italian composers of violin sonatas ca. 1730, such as Somis, Tartini, and Locatelli. In their works, three-movement cycles of binary movements are the norm, and interest in the traditional dance movements of the sonata da camera and the traditional fugal movements of the sonata da chiesa had long since disappeared. In 1732, there was only one important precedent in keyboard music in Italy for the use of formats similar to the Corellian sonata da camera: the four harpsichord sonatas of Domenico Zipoli's Sonate d'intavolatura of $1716 .{ }^{47}$ Zipoli's conception is much more rigid than what is seen in the sonatas of Giustini and Veracini, however (strictly an opening prelude followed by a narrow range of dance styles).

Giustini may have used Veracini's sonatas for stylistic guidance in some respects, but in others, his sonatas draw on well-established keyboard traditions. Alongside continuo textures similar to violin sonata writing, many passages exemplify the transparent two-part textures typical of Italian keyboard music of the 1720s and 1730s. Some influence from Della Ciaja's sonatas may also be at work. The Sienese Bernardino Azzolino Della Ciaja (1671-1755) published his Op. 4 sonatas in 1727 near the end of a long period of activity in Rome (17131730), after which he returned to Tuscany to live as a resident of Pisa from 1730 until his death. The themes of Giustini's fugal movements have much the same incisive character of Veracini's fugal themes instead of the nervous, overly-ornamented themes of Della Ciaja (see Example 5), but Giustini did choose to use the old-fashioned designation 'canzone' for them, just as Della Ciaja did. Seemingly as a confirmation of their connection to the venerable contrapuntal organ sonata, two of Giustini's second-movement fugues are in alla breve time (Sonatas nos. 5 and 10). In some passages, such as the opening of Giustini's Sonata No. 5, there is something like the

46. About the only other place that French overture style can be found in the repertory of early Italian keyboard sonatas is in Giovanni Battista Pescetti's Sonate per gravicembalo, published in London in 1739 while Pescetti was resident there. The prestige of French music in England at this time obviously provides an explanation for this.

47. The only other recent precedent in keyboard music for the inclusion of dances in a sonata would have been a set of sonatas by the Bolognese expatriate Pietro Giuseppe Sandoni published in London in the late 1720s. It is difficult to see how Giustini could have come across them, besides which the style of Sandoni's dances, unlike Giustini's, seems to have been influenced by Handel's suites for harpsichord. 
chromatic 'brooding' style that opens the 'toccata' movements of Della Ciaja's sonatas (see Example 6). Relentless series of downward-moving motivic ideas are a hallmark of Della Ciaja's 'toccata' movements, but their presence in Giustini's sonatas may also be attributed to improvisational habits common to many keyboard artists of the time. The use of French style brisé is not as prominent as in the keyboard sonatas of Padre Martini, but it is encountered occasionally. The principal structural cadences of the Corrente of Sonata no. 2 provide some of the most characteristic examples.

This discussion until now has emphasized stylistic traits in Giustini's sonatas that are somewhat archaic, but it should be emphasized that many stylistic features of Giustini's sonatas make them fully modern for the 1730 s, in fact quite compatible with the galant style of early classicism prevalent in Italy at that time. One of the most important galant traits to be found in the collection is a reliance on repetition as a technique of melodic expansion in place of the older technique of sequence. In the 1730 s, it was common for composers like Giustini to mix repetition and sequence in their movements. Repetition was favored for opening phrases and cadential flourishes, whereas sequence was used to help fill out the interior of binary-form segments. Rhythmic complications, generous sprinklings of grace notes, triplet figures, and variants of the 'Lombardian' rhythm help fill out their galant profile. A feature of Giustini's sonatas that might genuinely be referred to as innovative is occasional attempts to unify the cycles of movements with recurring musical motives. The best example of this technique is seen in the Sonata no. 11, which contains several movements based on a recurring thirty-second note motive at the start and syncopated cadential motives near the close of the binary-form segments. One critic, Bernard Frum, considered this sonata an 'early' example of an instrumental composition that uses a 'quasi-dramatic "plot" extending over more than one movement' ${ }^{48}$ Apparently the recurring motives struck Frum as the equivalent of dramatic characters. The idea is intriguing, but Frum failed to offer evidence that would lead one to believe that any such principle is actually at work in this composition.

Giustini's sonatas contain a wealth of charming and graceful musical ideas, but attractive and well-constructed as they are, they have little to offer modern pianists in the way of expressive power or virtuosic brilliance,' an important reason for their continued obscurity. For performers on historical instruments, they have much more potential as concert material, and there is no reason why harpsichordists should shun them, as they have done in the past. It is true that Giustini tried to tailor his sonatas to the capabilities of the Cristofori piano, the most obvious sign of this the addition of many dynamic markings. Dynamic markings are not found in every movement, however, and in most cases, their omission would not destroy the sense of the music. Few dynamic markings appear in Giustini's sonatas other than piano and forte, and they are usually employed to create simple 'echo' effects, that is to say enhance the sense of contrast

48. See Bernard Frum, 'An Early Example of Dramatic Procedures in 18th-Century Keyboard Music', The Musical Quarterly, 66 (1970), 230-46. 
when a phrase or motive is repeated at a different pitch level. The typical treatment is seen in Example 7. As a means of working out compositions that employ repeated phrases as a technique of expansion, a change of pitch level helps to mitigate the monotony of repetition, whether or not it is accompanied by a change in dynamic. This characteristic renders the majority of the Giustini movements quite effective if played on harpsichord, just as with the sonata (No. 7 in G major) that actually does survive in a manuscript in Brescia without dynamic markings. The few movements that contain more sophisticated manipulation of dynamic effects (such as crescendi) or evoke a certain 'atmosphere' created by the resonance of the hammered string are more clearly appropriate for the Cristofori piano. The movements marked 'affetuoso' and 'dolce' most typically belong to the latter category (as in Examples 4 and 7), but even these movements would sound acceptable on harpsichord, just not 'optimum'.

No fresh discussion of Giustini's sonatas could be considered complete without a response to theories advanced by Joel Sheveloff concerning the possible composition of some of the sonatas of Scarlatti for piano. ${ }^{49}$ Since the only keyboard music from the first half of the eighteenth century with explicit indication of preferred performance on piano was Giustini's Op. 1 (a collection that Scarlatti may well have known), Sheveloff tried to find common stylistic traits that might be interpreted as traces of shared techniques suitable for the piano. The presence of dynamic markings would be the best confirmation by far of an intent to compose sonatas with piano in mind, but since there are none in Scarlatti's sonatas, Sheveloff sought to draw attention to another device: acciaccature. Sheveloff predicted that 'a minimum of 200 [of Scarlatti's] sonatas will come to be associated with the pianoforte' simply by identifying Scarlatti sonatas that contain examples of a certain type of acciaccatura (no matter how few) and require a compass that could be accommodated by the pianos owned by Scarlatti's patroness the queen of Spain. ${ }^{50}$

Sheveloff stated that the Giustini sonatas were the only other compositions known to him that contained acciaccature notated in a certain way that is commonly found in the Scarlatti sonatas, i.e., with the dissonant tones given the same note values as the harmonic tones (in the work of most composers, acciaccature are notated as small-note graces). It should not come as a surprise that the practice of Giustini and Scarlatti is not unique. The same notational practice is found in the first 'toccata' of Della Ciaja's Op. 4 harpsichord sonatas, and many more examples are found in a collection of late seventeenth-century harpsichord music probably from Florence that is reproduced in the series 17 th Century Keyboard Music. ${ }^{51}$ Once again, musical traditions from Giustini's native Tuscany provided a key stylistic resource for his sonatas.

49. See Joel Sheveloff, 'Domenico Scarlatti: Tercentenary Frustrations (Part II)', The Musical Quarterly, 72 (1986), 90-101; idem, 'The Keyboard Music of Domenico Scarlatti: A Re-Evaluation of the Present State of Knowledge in the Light of the Sources' (Ph.D. diss., Brandeis University, 1970), 319-58.

50. Sheveloff, 'Tercentanary Frustrations', 101.

51. See Florence, Biblioteca del Conservatorio de Musica Luigi Cherubini, MS D. 2534, reproduced in vol. 10 of the series. Alexander Silbiger has dated the manuscript at between 1670 and 1700 . It contains preludes, toccatas, and dances without attribution to any composer. 
There is no escaping the view that Sheveloff greatly exaggerated the significance of the use of this type of acciaccatura in Giustini's sonatas, besides misrepresenting Giustini's treatment of texture and dynamics with reference to the capabilities of the Cristofori piano. ${ }^{52}$ Examples of largenote acciaccature are found in only eight of the fifty-three movements of Giustini's Op. 1, generally only one or two in the few movements where they do appear. Only one movement, the first movement of Sonata no. 5, which is labelled "Adagio, e arpeggiato nell' acciaccature" contains a few more. ${ }^{53}$ The large-note acciaccature are employed only to make a few cadences more emphatic by adding a bit more dissonance and a bit more dynamic volume to the dominant seventh chord that precedes the tonic chord. The way this effect is created can be seen in Example 8a. Note how the keynote is carried over from the second inversion of the tonic chord into the dominant seventh chord in mm. 6 and 15. Precisely the same technique can be found in the Florentine manuscript mentioned above (see Example 8b). Only in the first movement of the Sonata no. 5 are acciaccature of this type used in a slightly different way: to ornament imperfect cadences with appoggiaturas (see Example 6). With very few exceptions (for example the Sonatas, K. 54, 124, and 263), Scarlatti never used large-note acciaccature as cadential enhancements at the end of binary-form segments. Rather, they are used within the interior of binary-form segments to add harmonic color or dynamic gradations that could not be achieved by other means on harpsichord.

After a period of nearly two decades, it can be observed safely that performers and scholars do not 'associate' ca. 200 Scarlatti keyboard sonatas with the piano. Neither Sheveloff nor any other scholar has ever identified specific stylistic traits that would indicate that any of Scarlatti's sonatas was conceived primarily for performance on early pianos. Even if Scarlatti did somehow pick up his fondness for large-note acciaccature from Giustini, it is not clear at all how they are particularly idiomatic for piano, especially since it can be established that their use predates the invention of the instrument. ${ }^{54}$ David Sutherland has offered convincing reasoning to

52. According to Sheveloff ('Tercentenary Frustrations', 95), Giustini tended to 'gravitate toward toward the middle range [of the piano keyboard], avoiding extremes of high and low save at certain key moments', supposedly because the high notes of early pianos were 'weak in tone and penetrating ability'. In fact, every major keyboard composer that one can name from the early eighteenth century tends to concentrate on middle ranges primarily and avoids extremes of high and low, a defining feature of keyboard music from this era that is based on part-writing derived from vocal ranges. It is difficult to reconcile Sheveloff's claim that high ranges of the early pianos were weak with his observation that Giustini thinned out his textures when the melody goes high (if the upper range is so weak, would it not be more logical to strengthen the sonorites, not thin them out?). Actually there is no consistent correlation between the treatment of dynamics and texture in Giustini's sonatas and the range of the melodic lines; variety in treatment appears to have been his goal.

53. Sheveloff considerately tabulated all of the uses of the device that he could find in the Giustini sonatas both in his dissertation and the 'Tercentenary Frustrations'. In Sonata no. 1 there are examples in movements 1 (mm. 2 and 12) and 3 (mm. 14); in Sonata no. 3 in movement 3 (mm. 6 and 15); in Sonata no. 4 in movement 1 (mm. 8 and 17); in Sonata no. 5 in movement 1 (mm. 2-3, 7, 19-21, 28-30, and 39); in Sonata no. 7 in movements 1 (m. 37) and 2 (m. 105); and one example in the second movement of Sonata $11(\mathrm{~m} .11)$. Sheveloff mis-analyzed the dissonances found in mm. $71-72$ of the second movement of Sonata no. 7 as acciaccature; they are actually suspensions that resolve conventionally. He missed a strange cluster in the first movement of Sonata no. 11 (m. 2) that appears to be a mistake in the print (the lowest pitch in the right hand should probably be a 'b', not a 'c').

54. Sheveloff did advance theories suggesting that the acciaccature would somehow not sound as harsh when played on early pianos, especially if the performers exploited the dynamic capabilities of the instruments in ways that are not explained clearly ('Tercentenary Frustrations', 108). In fact, there is no evidence that any pianistic technique distinct from harpsichord technique existed in the early eighteenth century that might lead performers to play dissonant tones at some sort of softer dynamic level. 
suggest that Scarlatti must have performed his sonatas frequently on the pianos that were owned by the court of Spain, ${ }^{55}$ but this does not mean that any of them were necessarily tailored for the piano as an instrument of preference. Certain Scarlatti sonatas can be played effectively either on harpsichord or piano with Cristofori action, to say nothing of organ, clavichord, or modern piano. As a group, they are best considered compositions for keyboard without pedal that were not intended to be realized exclusively on a specific type of keyboard instrument.

Except for the Op. 1 sonatas of Lodovico Giustini, it was not until the 1760s that composers and publishers started to take care to indicate the pianoforte as an instrument of preference for keyboard music, at first almost always as an option paired with harpsichord. ${ }^{56}$ Undoubtedly this was a reflection of a long-standing performance practice that left open the choice of keyboard instrument for the realization of keyboard music. Regardless of the designations that appeared on musical scores, performers on pianoforte could easily add their own dynamic effects to compositions that specified none just as easily as harpsichordists could ignore any that were entered. Until the late eighteenth century, the only critical impediment to performance on a given instrument would have been nothing more than the available compass. In Italian usage, the specification of 'cembalo' probably should not be taken to mean 'harpsichord' exclusively, but any wing-shaped keyboard instrument. ${ }^{57}$ For most composers and publishers in the early and mid-eighteenth century, a more precise designation simply did not matter.

The designation did matter to those responsible for publishing Giustini's Op. 1 sonatas, however, and one wonders why. The answer way well lie in connections with the royal court of Portugal. It has recently come to light that King João V of Portugal ordered pianos directly from Bartolomeo Cristofori in the years before his death in 1732 at very great expense to the court. ${ }^{58}$ One suspects that Giustini's sonatas were brought to Portugal as a sort of accouterment for these extravagant purchases, possibly a means to justify them. It would seem that care was taken to obtain high-quality music from Florence to go with the Florentine instruments, hence the unusual

55. See David Sutherland, 'Domenico Scarlatti and the Florentine Piano', Early Music, 23 (1995), 243-56.

56. See William S. Newman, The Sonata in the Classic Era, 83-89, for a concise overview of the sonata collections from the 1760 s that specify pianoforte in their title pages. Rosamond Harding, in her article 'The Earliest Pianoforte Music', 199, drew attention to what she believed was the first collection after Giustini's to specify performance on pianoforte without the option of harpsichord: Salvador Pazzaglia's Sei sonate da cimablo per il piano, e forte col accompagnato del violino (Florence, n.d.). Harding believed the print to date from about 1760 , however its dedication to the Archduchess Maria Theresia of Austria proves otherwise. The dedicatee, born in Florence in 1767, was the eldest daughter of the Archduke Leopold of Austria, at that time Grand Duke of Tuscany (later Holy Roman Emperor as Leopold II), and a nemesis of Mozart at the time of the preparations in Prague for the première of Don Giovanni, which coincided with her honeymoon. The Pazzaglia print must date before 1787, when Maria Theresia's title changed. In that year, she became Crown Princess of Saxony upon her marriage in Dresden to Prince Anton of Saxony (she was briefly Queen of Saxony before her death in 1827). Likely the print was produced in the early or mid-1780s. There is no mention of it in Newman, The Sonata in the Classic Era. The earliest publication after the Giustini sonatas to indicate piano as sole instrument of preference has not been established. 57. The importance of this principle is emphasized in Sutherland, 'Bartolomeo Cristofori's Paired Cembalos of 1726'. Ambiguity in this matter is not confined to Italian. Consider, for example, Ferdinando Pellegrini's Six Lessons for the Harpsichord published in London in the 1760s. The specification for harpsichord as the instrument of preference seems clear enough, however the pieces contained in the print are full of dynamic markings.

58. See Stewart Pollens, The Early Pianoforte (Cambridge, 1995), 118. 
specificity in designating an instrument of preference and the precise position of dynamic markings in the score. One way to interpret the genesis of Giustini's Op. 1 print is to imagine Seixas arriving at the court of Lisbon in 1734 and recognizing quickly that there was a need for piano music there, then offering to obtain a fine collection of it from Italy that he already knew about.

To bring to a close this fresh consideration of the origins and style of the earliest surviving music specifically intended for performance on piano, it is appropriate to return to the theme of irony raised in the opening paragraph. The creator of this music, Lodovico Giustini, was a composer quite parochial in training and personal experiences who succeeded in producing as his only widely-disseminated compositions an unusually eclectic and cosmopolitan set of keyboard sonatas. The best explanation for this achievement lies in the availability of eclectic and cosmopolitan compositional models in Tuscany, especially a collection of sonatas by Francesco Maria Veracini that just happened to have been composed with Frenchified traits in the German city of Dresden. The Giustini sonatas are the product of what appears to have been a rare chance for their author to visit a great cultural center in nearness to his native city of Pistoia and take advantage of the opportunities presented by contact (direct or indirect) with three remarkable individuals who happened to reside there in the early 1730s: an instrument maker (Bartolomeo Cristofori), a composer (Francesco Maria Veracini), and a patron with international connections (João de Seixas). 


\section{Musical Examples}

Example 1a:

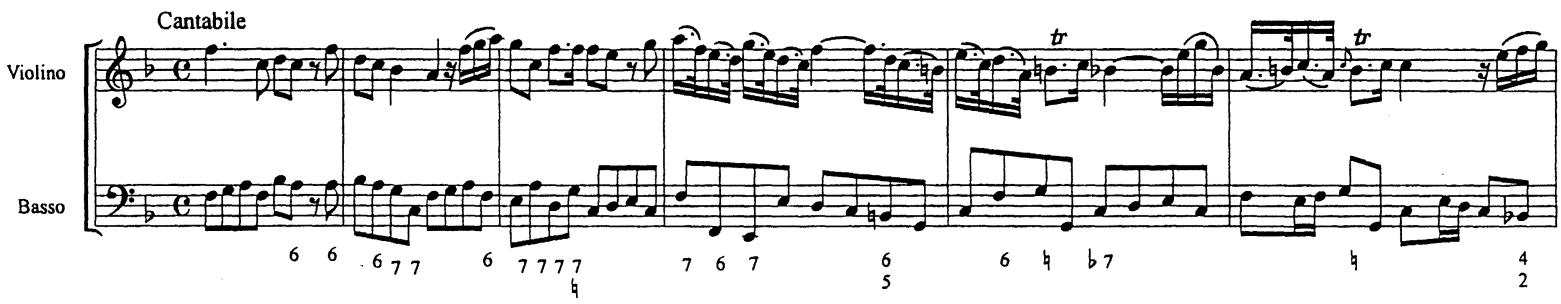

Francesco Maria Veracini:

Sonata for Violin and Basso Continuo in F major, Op. 1, no. 12, first movement, mm. 1-6.

\section{Example lb:}

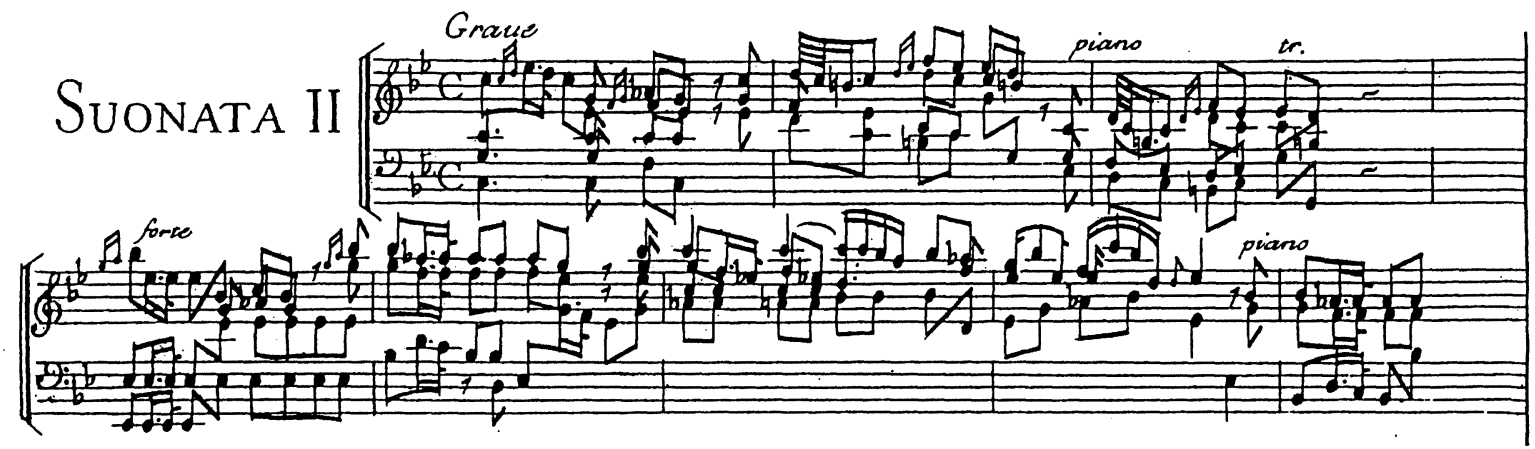

Lodovico Giustini:

Pianoforte Sonata in C minor, Op. 1, no. 2, first movement, mm. 1-8.

\section{Example 2a:}

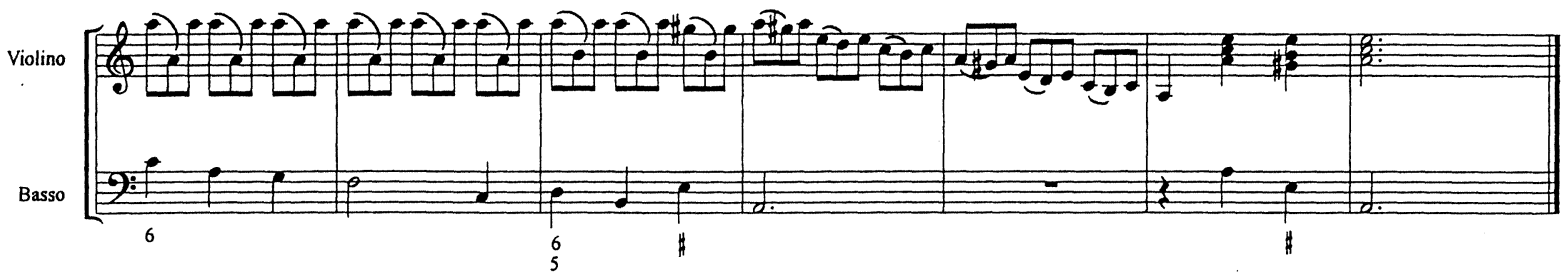

Francesco Maria Veracini:

Sonata for Violin and Basso Continuo in A minor, Op. 1, no. 2, fifth movement, mm. 150-56. 


\section{Example 2b:}

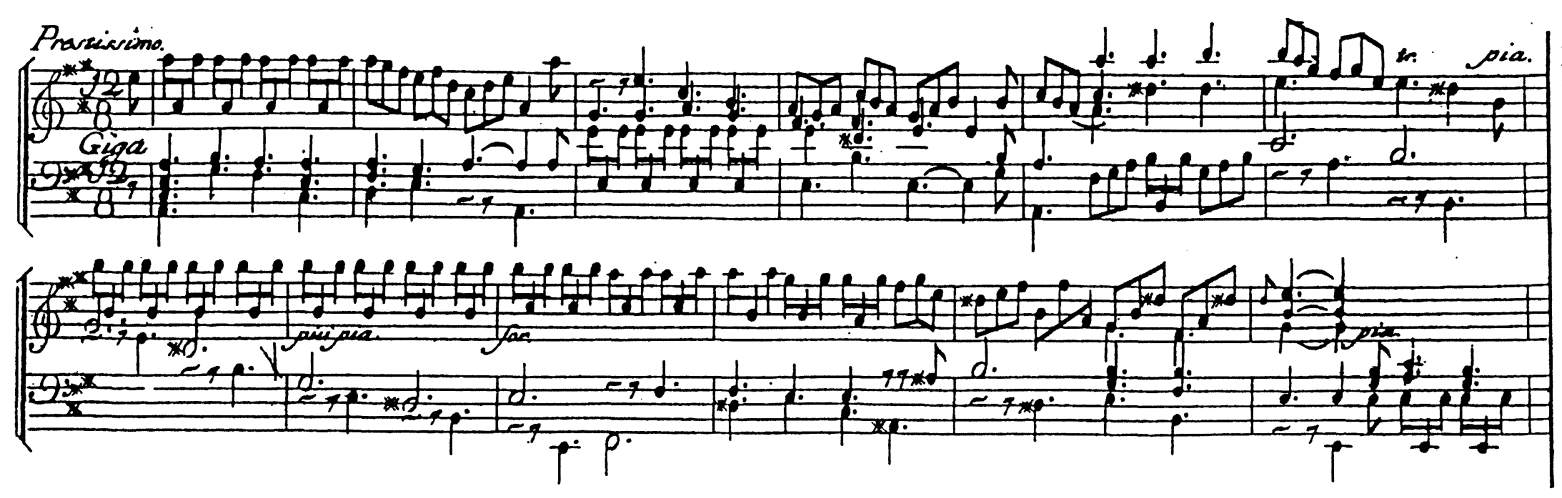

Lodovico Giustini:

Pianoforte Sonata in A major, Op. 1, no. 8, fourth movement, mm. 1-12.

Example 3a:

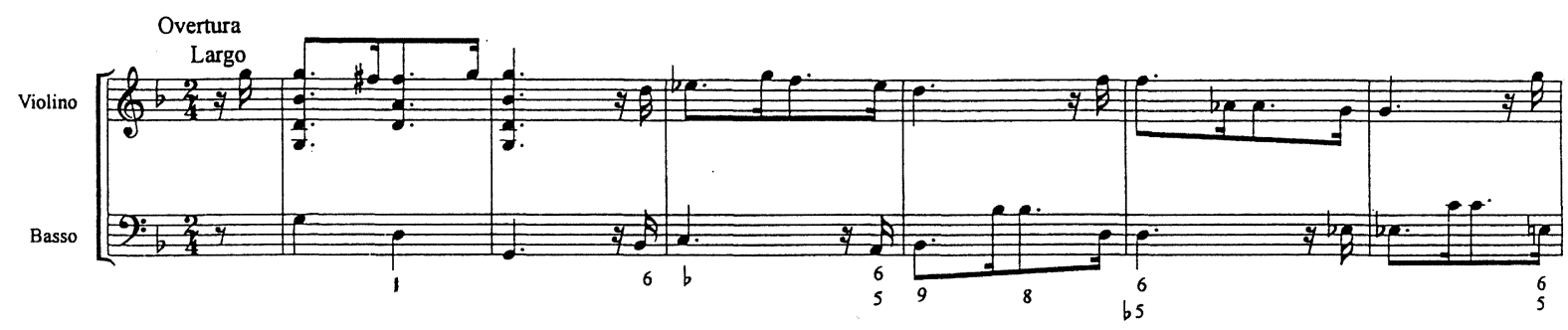

Francesco Maria Veracini:

Sonata for Violin and Basso Continuo in G minor, Op. 1, no. 1, first movement, mm. 1-14.

\section{Example 3b:}

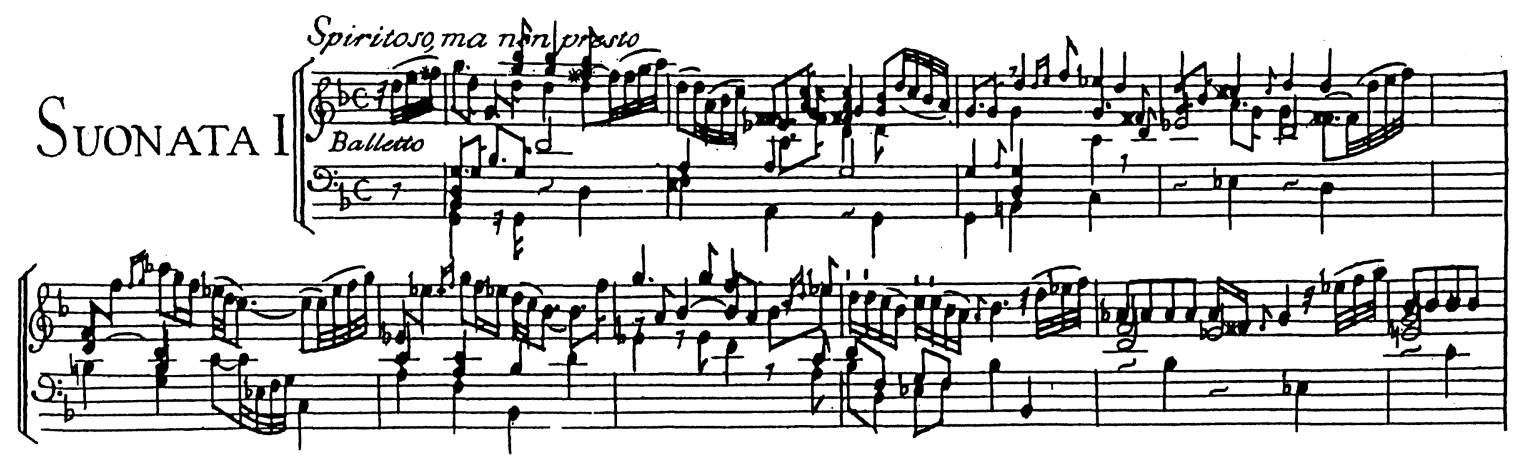

Lodovico Giustini: Pianoforte Sonata in G minor, Op. 1, no. 1, first movement, mm. 1-10. 


\section{Example 4a:}

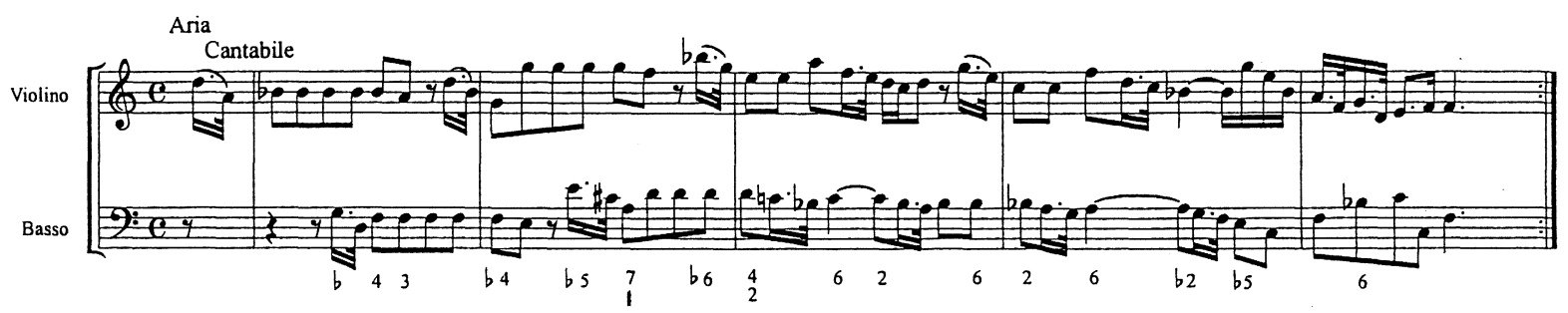

Francesco Maria Veracini:

Sonata for Violin and Basso Continuo in D minor, Op. 1, no. 5, third movement, mm. 1-5.

Example 4b:

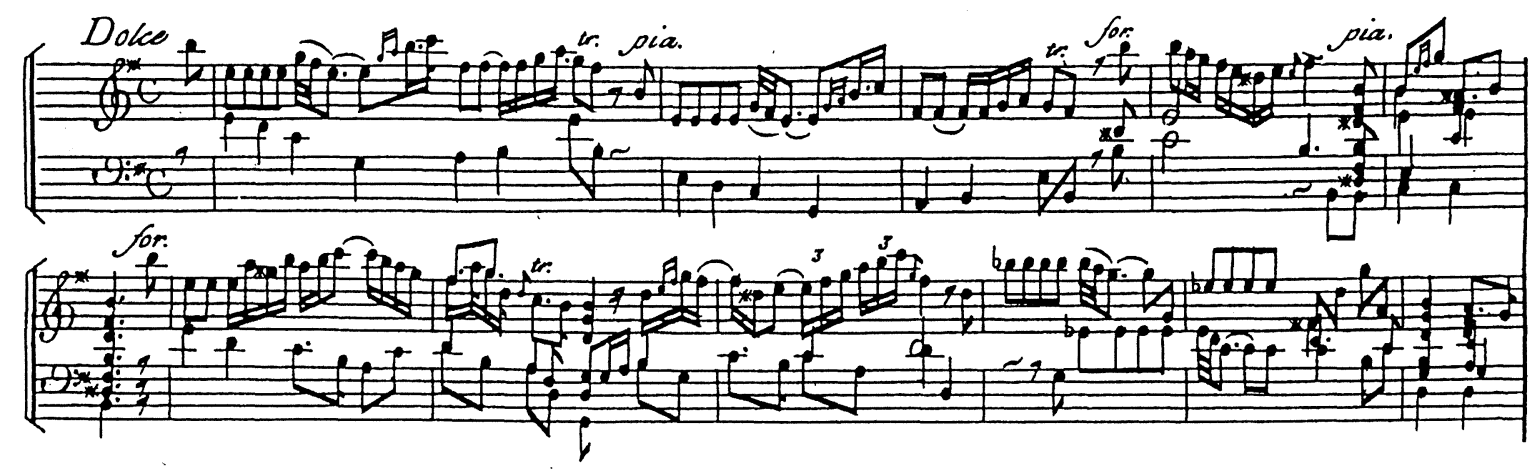

Lodovico Giustini:

Pianoforte Sonata in E maior, Op. 1, no. 9, second movement, mm. 1-11.

Example 5a:

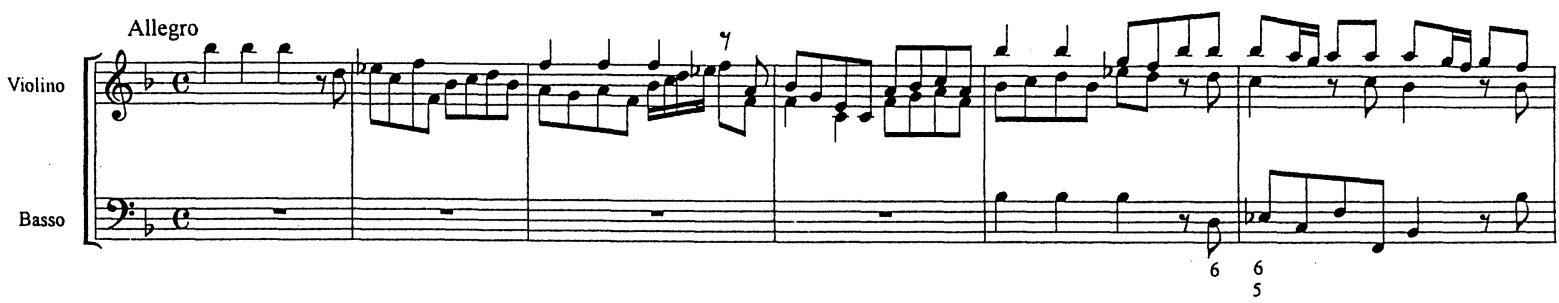

Francesco Maria Veracini:

Sonata for Violin and Basso Continuo in B-flat major, Op. 1, no. 8, second movement, mm. 1-6. 
Example 5b:

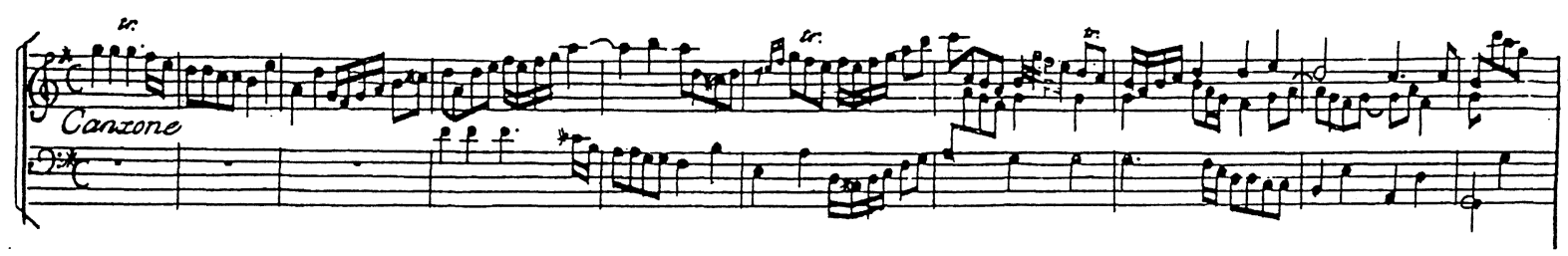

Lodovico Giustini:

Pianoforte Sonata in G major, Op. 1, no. 12, second movement, mm. 1-10.

\section{Example 5c:}
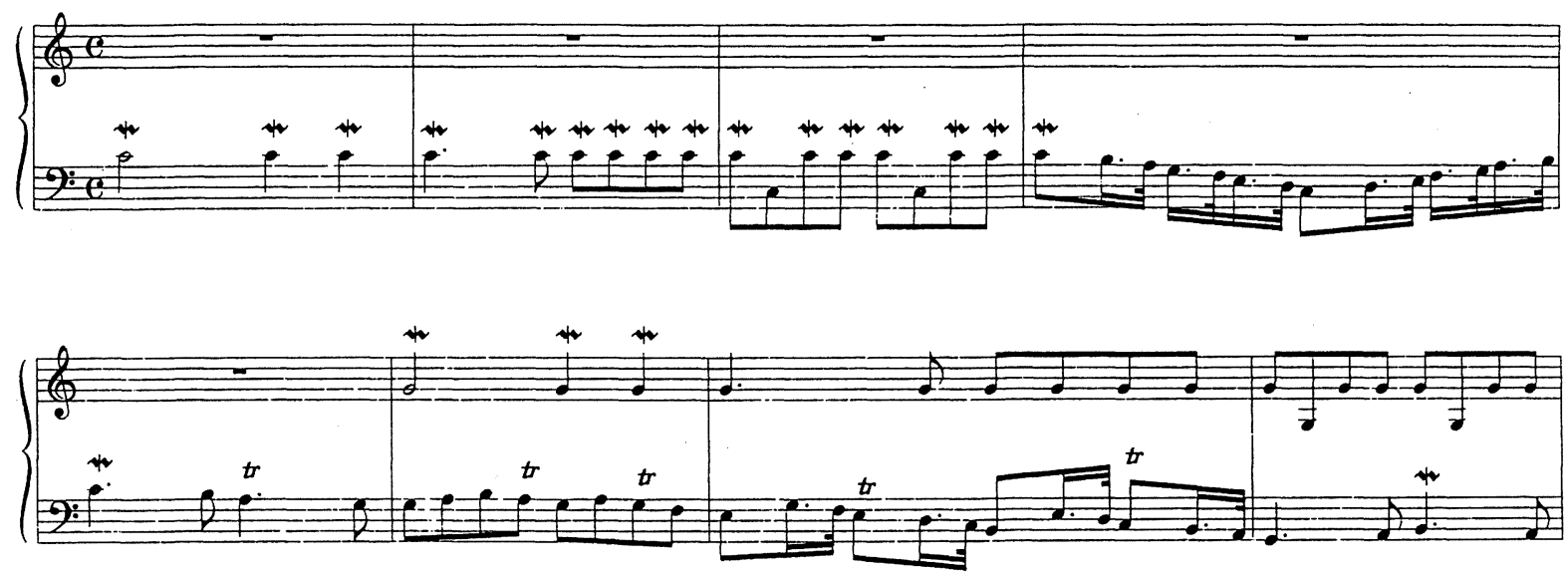

Bernardino Azzolino della Ciaja:

Keyboard Sonata in C major, Op. 4, no. 1, second movement, mm. 1-8. 
Example 6:

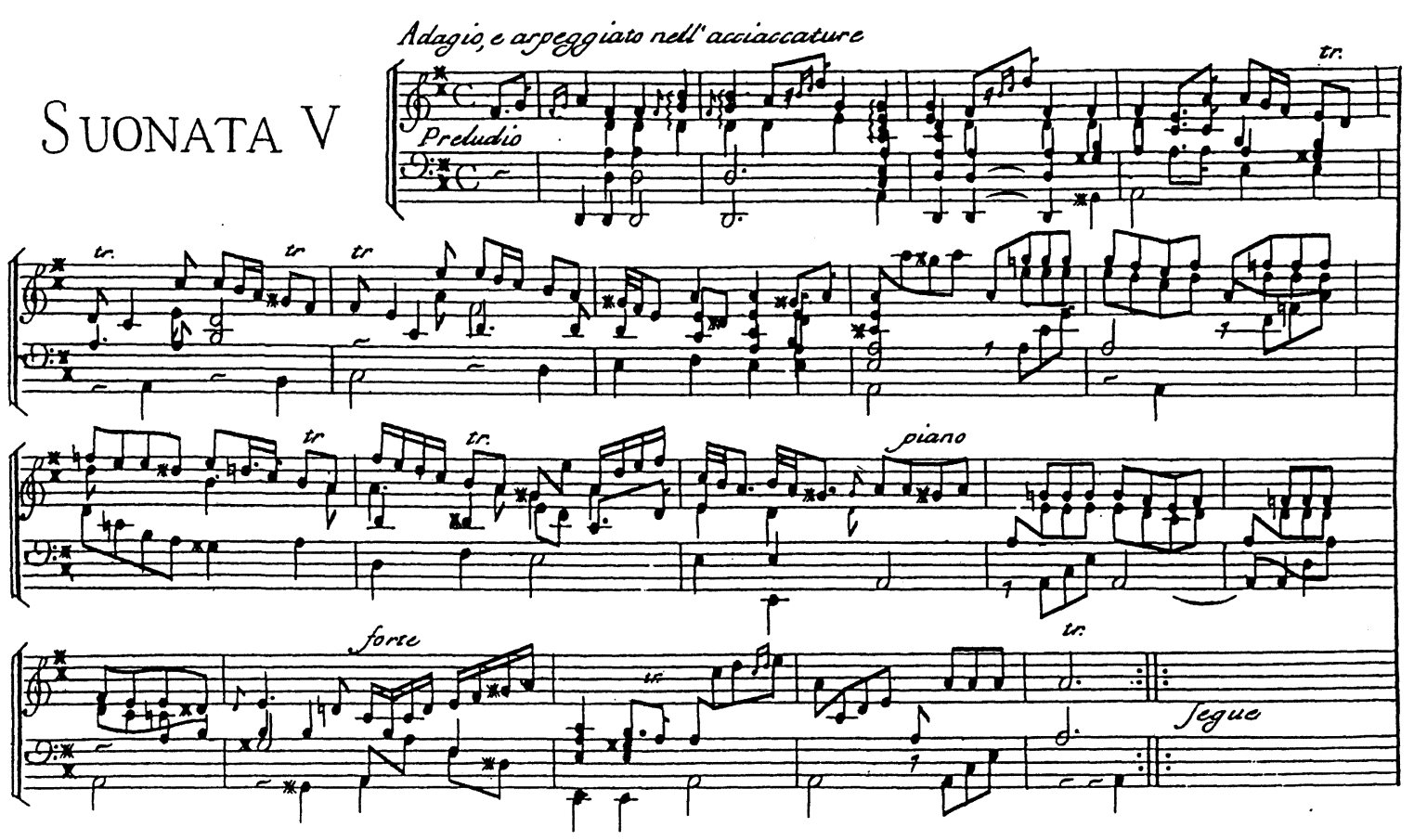

Lodovico Giustini:

Pianoforte Sonata in D major, Op. 1, no. 5, first movement, mm. 1-18.

\section{Example 7:}

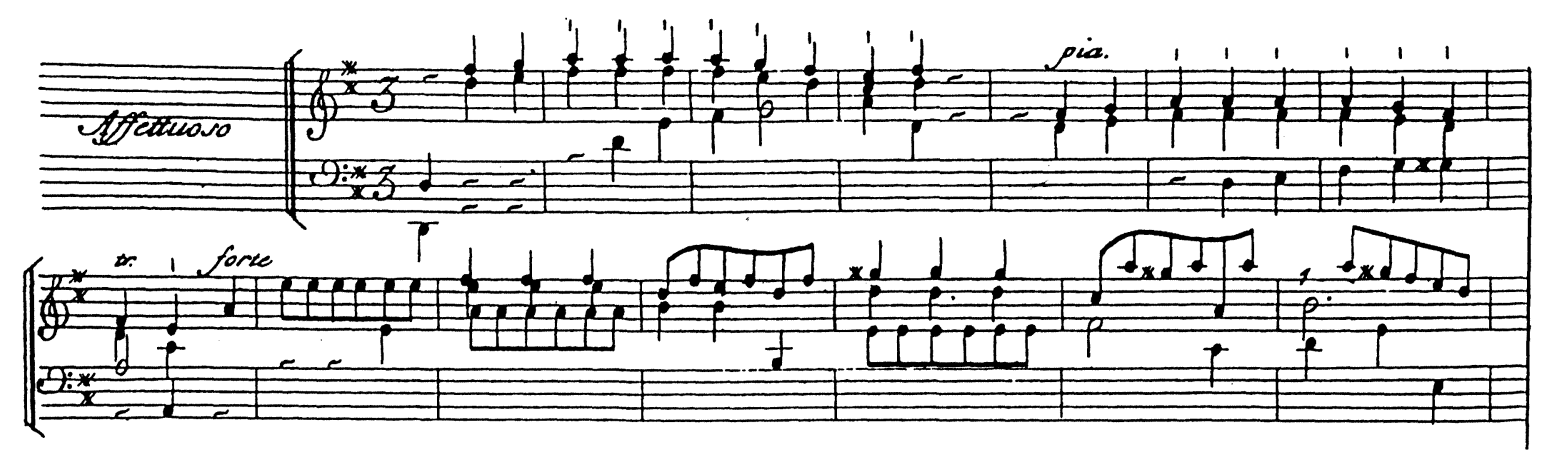

Lodovico Giustini:

Pianoforte Sonata in D major, Op. 1, no. 5, third movement, mm. 1-14. 


\section{Example 8a:}

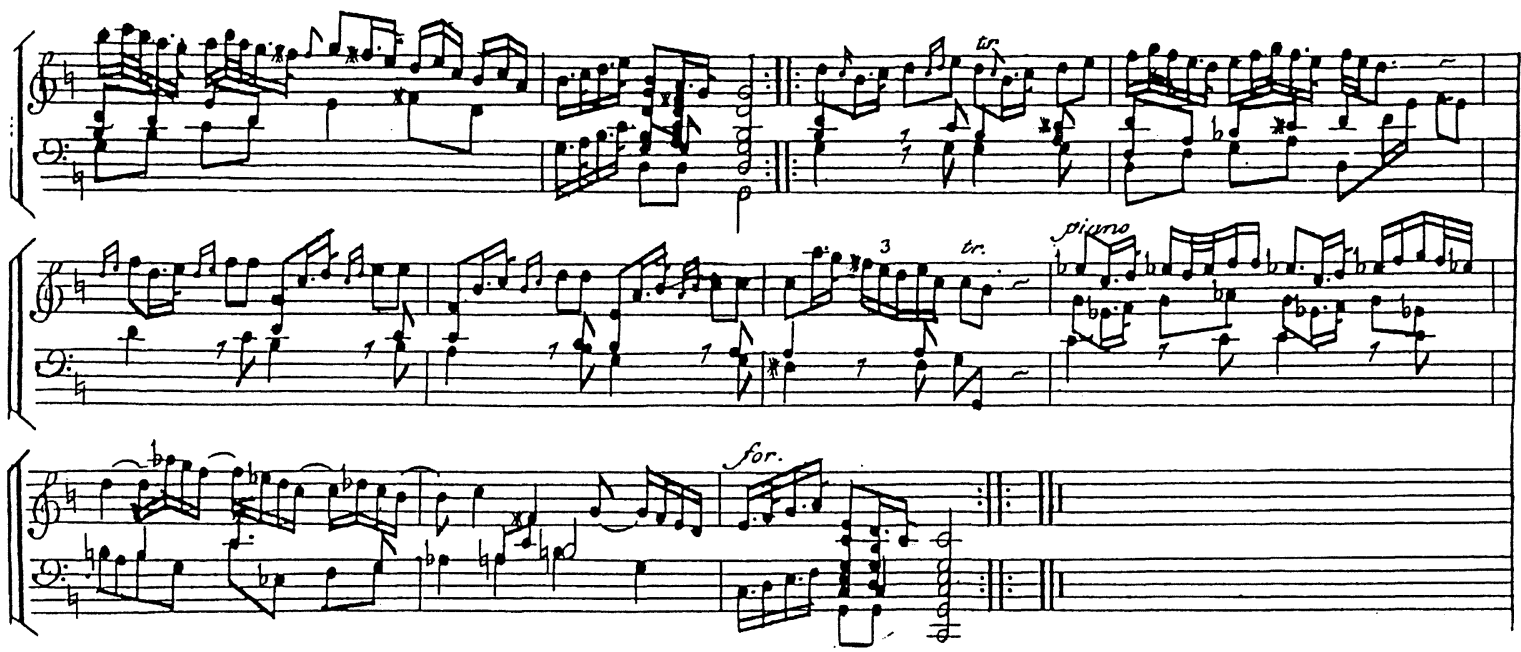

Lodovico Giustini:

Pianoforte Sonata in F major, Op. 1, no. 3, third movement, mm. 5-15.

\section{Example 8b:}

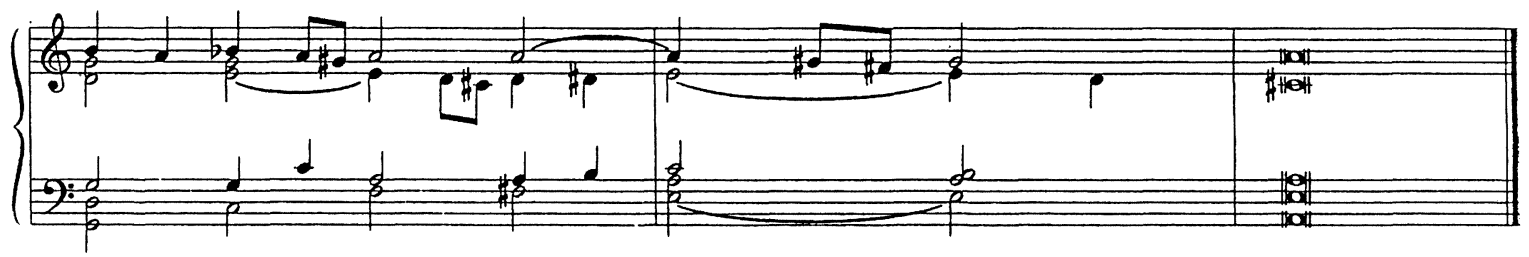

Anonymous:

'Preludio di botte, acciachature, e ligature' from the manuscript Florence,

Conservatorio di Musica Luigi Cherubini, D. 2534, ff. 6'-8', mm. 31-33. 


\section{Table 1}

Francesco Maria Veracini's Violin Sonatas, Op. 1 (ca. 1720)

Disposition of Movements

\begin{tabular}{|c|c|c|}
\hline No. 1 (G minor) & No. 2 (A minor) & No. 3 (B minor) \\
\hline $\begin{array}{c}\text { Overtura: Largo; } \\
\text { Allegro } \\
\text { Aria: Affetuoso } \\
\text { Paesana } \\
\text { Minuet } \\
\text { Giga }\end{array}$ & $\begin{array}{l}\text { Preludio: Adagio } \\
\text { Allemanda } \\
\text { Siciliana: Cantabile } \\
\text { Grave } \\
\text { Aria }\end{array}$ & $\begin{array}{c}\text { Preludio: Largo } \\
\text { Allemanda } \\
\text { Largo } \\
\text { Rondò }\end{array}$ \\
\hline No. 4 (C minor) & No. 5 (D minor) & No. 6 (E minor) \\
\hline $\begin{array}{c}\text { Preludio: Largo } \\
\text { Allegro } \\
\text { Sarabande } \\
\text { Allegro }\end{array}$ & $\begin{array}{c}\text { Preludio: Andante } \\
\text { Corrente } \\
\text { Aria: Cantabile } \\
\text { Giga }\end{array}$ & $\begin{array}{c}\text { Fantasia: Largo } \\
\text { Allegro assai } \\
\text { Allemanda } \\
\text { Pastorale } \\
\text { Giga }\end{array}$ \\
\hline No. 7 (A major) & No. 8 (B-flat major) & No. 9 (C major) \\
\hline $\begin{array}{c}\text { Cantabile } \\
\text { Larghetto } \\
\text { Allegro } \\
\text { Largo } \\
\text { Allegro }\end{array}$ & $\begin{array}{c}\text { Largo } \\
\text { Allegro [fugue] } \\
\text { Allegro } \\
\text { Grave } \\
\text { Allegro }\end{array}$ & $\begin{array}{l}\text { Largo e staccato } \\
\text { Allegro [fugue] } \\
\text { Vivace } \\
\text { Largo } \\
\text { Allegro [fugue] }\end{array}$ \\
\hline No. 10 (D major) & No. 11 (E major) & No. 12 (F major) \\
\hline $\begin{array}{c}\text { Largo } \\
\text { Allegro [fugue] } \\
\text { Allegro } \\
\text { Largo } \\
\text { Brillante [fugue] }\end{array}$ & $\begin{array}{c}\text { Cantabile } \\
\text { Allegro [fugue] } \\
\text { Allegro } \\
\text { Largo } \\
\text { Allegro [fugue] }\end{array}$ & $\begin{array}{c}\text { Cantabile } \\
\text { Larghetto } \\
\text { Intermedio: Aria } \\
\text { (Affetuoso) } \\
\text { Aria: Cantabile } \\
\text { Capriccio: Allegro }\end{array}$ \\
\hline
\end{tabular}




\section{Table 2}

\section{Lodovico Giustini's Pianoforte Sonatas, Op. 1 (1732)}

Disposition of Movements

\begin{tabular}{|c|c|c|}
\hline No. 1 (G minor) & No. 2 (C minor) & No. 3 (F major) \\
\hline $\begin{array}{l}\text { Balletto: Spiritoso, } \\
\text { ma non presto } \\
\text { Corrente } \\
\text { Sarabanda } \\
\text { Giga } \\
\text { Minuet: Affetuoso }\end{array}$ & $\begin{array}{c}\text { Grave } \\
\text { Corrente } \\
\text { Giga (Grave) } \\
\text { Giga } \\
\text { Minuet }\end{array}$ & $\begin{array}{c}\text { Siciliana: Affetuoso } \\
\text { Canzone [fugue] } \\
\text { Andante, } \\
\text { ma non presto } \\
\text { Giga [fugue] }\end{array}$ \\
\hline No. 4 (E minor) & No. 5 (D major) & No. 6 (B-flat major) \\
\hline $\begin{array}{l}\text { Preludio: Largo } \\
\text { Presto } \\
\text { Sarabanda } \\
\text { Giga }\end{array}$ & $\begin{array}{l}\text { Preludio: Adagio, } \\
\text { e arpeggiato nell' } \\
\text { acciaccature } \\
\text { Allegro [fugue] } \\
\text { Affetuoso } \\
\text { Corrente } \\
\text { Tempo di Gavotta }\end{array}$ & $\begin{array}{c}\text { Preludio: Grave } \\
\text { Allegro assai } \\
\text { Dolce } \\
\text { Giga }\end{array}$ \\
\hline No. 7 (G major) & No. 8 (A major) & No. 9 (C major) \\
\hline $\begin{array}{l}\text { Allemanda } \\
\text { Corrente } \\
\text { Siciliana } \\
\text { Gavotta }\end{array}$ & $\begin{array}{c}\text { Sarabanda: Affetuoso } \\
\text { Allegro } \\
\text { Rondò: Affetuoso } \\
\text { Giga }\end{array}$ & $\begin{array}{c}\text { Sarabanda } \\
\text { Allemanda } \\
\text { Rondò: Affetuoso } \\
\text { Gavotta }\end{array}$ \\
\hline No. 10 (F minor) & No. 11 (E major) & No. 12 (G major) \\
\hline $\begin{array}{l}\text { Allemanda: Affetuoso } \\
\text { Canzone [fugue]: } \\
\text { Tempo di Gavotta } \\
\text { Allemanda: Grave } \\
\text { ed Affetuoso } \\
\text { Corrente }\end{array}$ & $\begin{array}{c}\text { Allemanda } \\
\text { Dolce } \\
\text { Gavotta } \\
\text { Rondò: Affetuoso } \\
\text { Giga }\end{array}$ & $\begin{array}{c}\text { Sarabanda } \\
\text { Canzone [fugue] } \\
\text { Siciliana: Affetuoso } \\
\text { Giga } \\
\text { Minuet }\end{array}$ \\
\hline
\end{tabular}

